This PDF is a selection from an out-of-print volume from the National Bureau of Economic Research

Volume Title: The International Transmission of Inflation

Volume Author/Editor: Michael R. Darby, James R. Lothian and Arthur E.

Gandolfi, Anna J. Schwartz, Alan C. Stockman

Volume Publisher: University of Chicago Press

Volume ISBN: 0-226-13641-8

Volume URL: http://www.nber.org/books/darb83-1

Publication Date: 1983

Chapter Title: International Price Behavior and the Demand for Money

Chapter Author: Arthur E. Gandolfi, James R. Lothian

Chapter URL: http://www.nber.org/chapters/c6137

Chapter pages in book: (p. 421 - 461) 


\title{
14 International Price Behavior and the Demand for Money
}

\author{
Arthur E. Gandolfi and James R. Lothian
}

Oil prices, commodity prices, and American monetary policy, the last operating through a variety of channels, have all figured prominently in explanations of the international inflation process in the late 1960s and early 1970s. In this chapter, we test these various hypotheses within the context of a reduced-form rational expectations price equation that we have estimated for the United States and the seven other industrial countries in our sample. ${ }^{1}$

A key concern in the estimation of this model was the properties of the demand for money function. Unlike many studies using post-World War II time-series data that rely on the stock adjustment model, we obtain what we regard as reasonable estimates of the parameters of the long-run demand for money function-particularly the income elasticity-without having to posit unacceptably slow speeds of adjustment. The adjustment mechanism implicit in the estimated equation, in fact, is quite different from the standard formulation.

For all eight countries we find evidence of second-order serial correlation that is consistent with the existence of two types of error processes: permanent stochastic shifts that follow a random walk and other types of disturbances that, unlike the first sort, are transitory in nature. Hence a shock that alters the equilibrium rate of change of prices will gradually be eliminated, but the level of prices will not necessarily return to its original path.

With respect to the causes of inflation internationally, our results are consistent with those reported elsewhere in this volume. They suggest

An earlier, abbreviated version of this chapter was published in Economic Inquiry, the journal of the Western Economics Association, vol. 21, no. 3 (July 1983).

1. See chapter 3 for a description of the data. 
that domestic money supplies played the crucial role in the process. In the seven foreign countries, the increases in monetary growth underlying the increases in inflation came in response to both foreign monetary pressures and domestic factors. In the U.S., the reserve-currency country, domestic factors alone were important. Direct price arbitrage appears to have little additional effect in most countries. Oil price shocks, however, may have made some contribution to the increases in U.S. and most foreign price levels, but relative to domestic money they were clearly of secondary importance. ${ }^{2}$

\subsection{The Structural and Reduced-Form Price Equation}

Three equations make up the basic model: a money demand function, an aggregate supply function, and an expected money equation.

The money demand function takes the fairly conventional form

$$
(M / P)_{t}=\alpha+\beta_{1} y_{t}^{p}+\beta_{2} y_{t}^{t}+\beta_{3} r_{t},
$$

where $M / P$ is the log of real per capita cash balances, $y^{p}$ is the log of real per capita permanent income, $y^{t}$ is transitory income-defined as the difference between the logs of measured and permanent real incomeand $r$ is the log of the interest rate. ${ }^{3}$

The aggregate supply function is of the form used by Lucas (1973):

$$
y_{t}^{t}=\lambda y_{t-1}^{t}+\phi\left(P_{t}-P_{t}^{*}\right),
$$

where $P$ and $P^{*}$ are the logs of the actual and expected levels of prices, respectively.

Expected prices in this framework represent the cost of production. An increase in actual over expected price fools producers into believing that there has been a rise in the relative price of their product and induces an increase in output. The autocorrelation that is apparent in movements in real output has been rationalized by Blinder and Fischer (1978) as the result of using inventories to stabilize production. A positive price shock leads suppliers to increase their sales partially from increased production and partially from drawing down stocks of inventories. The shock will have a delayed effect on output as inventories are replaced slowly over time.

By solving for real transitory income in equation (14.1), substituting it into equation (14.2), and taking expected values of the variables, we derive the following equation for expected prices:

2. See chapter 3 , by Cassese and Lothian, using Granger causality tests, and chapter 5 by Darby and Stockman, using a simultaneous model, for corroborative evidence for these countries over this period. The study by Dewald and Marchon (1978) and various papers in the conference volume edited by Brunner and Meltzer (1978) also contain findings that are largely consistent with ours.

3. In the empirical work reported below, we use a long-term bond rate as the interestrate variable to reduce problems of simultaneity. 


$$
p_{t}^{*}=M_{t}^{*}-\alpha-\beta_{1} y_{t}^{p}-\lambda \beta_{2} y_{t-1}^{t}-\beta_{3} r_{t},
$$

where the asterisk denotes expected values. Substituting this expression into the aggregate supply equation (14.2) and rearranging terms yields the reduced-form price equation:

$$
\begin{aligned}
P_{t}= & -\alpha+M_{t}-\beta_{1} y_{t}^{p}-\beta_{2} \lambda y_{t-1}^{t} \\
& -\beta_{3} r_{t}-\frac{\phi \beta_{2}}{1+\phi \beta_{2}}\left(M-M^{*}\right)_{t} .
\end{aligned}
$$

Given the equations for $P$ and $P^{*}$, we can also derive a reduced-form real output relation:

$$
y_{t}^{t}=\lambda y_{t-1}^{t}+\frac{\phi}{1+\beta_{2} \phi}\left(M_{t}-M_{t}^{*}\right) .
$$

Using (14.5), we can then substitute for $y_{t-1}^{t}$ in the price equation (14.4) to arrive at the alternative form: ${ }^{4}$

$$
\begin{aligned}
P_{t}= & M_{t}-\alpha-\beta_{1} y_{t}^{p}-\beta_{3} r_{t} \\
& -\sum_{i=0}^{\infty} \frac{\lambda^{i} \beta_{2} \phi}{1+\beta_{2} \phi}\left(M-M^{*}\right)_{t-i} .
\end{aligned}
$$

The last term on the right-hand sides of (14.4) and of (14.6) is the monetary shock-the difference between the actual and the expected values of the nominal stock of money. The latter we determined empirically, from a variety of equations of the general form

$$
M_{t}=f\left(L\left(M_{t}\right), X\right),
$$

where $L$ is a lag operator and $X$ is a vector of variables that enter the monetary authority's reaction function.

\subsection{Estimates of the Price Equation}

In table 14.1 we report the estimates of equation (14.6) using M2 as the definition of money, the GNP or GDP deflator as the price variable, and Friedman's weighting scheme for our proxies for real permanent income. ${ }^{5}$ We constrained the coefficient for actual per capita nominal money balances to unity, so the dependent variable was $\log (P / M 2 N)$, the

4. The final form of our price equation is similar to the equation estimated by Barro (1978) with annual data for the United States.

5. Of the three monetary variables we tried, M1, M2, and high-powered money, M2 performed the best. The estimated coefficients were more consistent among countries and closer to what we regard as plausible magnitudes.

We derived the permanent income series using a logarithmic version of the method outlined in Darby (1972). The choice of weights was largely arbitrary. We wanted to use an a priori scheme and the two most likely-Darby's ( 0.10 annual weight) and Friedman's ( 0.33 annual weight) - produced no appreciable differences in the estimates. 
Table 14.1 Price Equation with Dependent Variable $\log P D-\log (\mathrm{M} 2 / N), 195711 \mathrm{II}$ to 1976IV (absolute value of $t$ statistic in parentheses)

\begin{tabular}{ccccccccc}
\hline & CA & FR & GE & IT & JA & NE & UK & US \\
\hline Coefficient & & & & & & & & \\
Constant & 3.096 & 0.678 & 4.121 & 11.733 & 3.540 & 0.614 & -1.948 & -0.684 \\
& $(3.977)$ & $(0.620)$ & $(7.480)$ & $(15.676)$ & $(7.323)$ & $(0.525)$ & $(1.217)$ & $(2.459)$ \\
ResM2 & -0.508 & -0.936 & -0.927 & -0.845 & -0.910 & -0.879 & -1.021 & -0.904 \\
& $(2.931)$ & $(9.717)$ & $(12.507)$ & $(5.387)$ & $(5.347)$ & $(8.549)$ & $(9.726)$ & $(10.071)$ \\
ResM2 & -1.099 & -1.044 & -0.686 & -0.645 & -1.078 & -0.846 & -0.842 & -1.571 \\
& $(4.813)$ & $(6.006)$ & $(5.049)$ & $(2.537)$ & $(4.024)$ & $(6.207)$ & $(5.215)$ & $(9.683)$ \\
ResM2 $_{t-2}$ & -0.860 & -0.842 & -0.561 & -0.523 & -1.096 & -0.837 & -0.771 & -1.592 \\
& $(3.675)$ & $(4.001)$ & $(3.157)$ & $(1.675)$ & $(3.911)$ & $(5.773)$ & $(4.031)$ & $(7.592)$ \\
ResM2 $_{t-3}$ & -0.897 & -0.581 & -0.600 & -0.292 & -1.002 & -0.620 & -0.941 & -1.276 \\
& $(4.210)$ & $(2.552)$ & $(3.080)$ & $(0.892)$ & $(3.934)$ & $(4.293)$ & $(4.853)$ & $(5.840)$ \\
ResM2 $_{t-4}$ & -0.731 & -0.441 & -0.404 & -0.104 & -0.863 & -0.523 & -0.745 & -0.809 \\
& $(3.150)$ & $(1.984)$ & $(2.178)$ & $(0.335)$ & $(3.146)$ & $(3.317)$ & $(3.826)$ & $(3.880)$
\end{tabular}




\begin{tabular}{lcccccccc} 
ResM2 ${ }_{t-5}$ & -0.973 & -0.205 & -0.221 & -0.127 & -0.373 & -0.333 & -0.591 & -0.533 \\
& $(4.367)$ & $(1.060)$ & $(1.473)$ & $(0.502)$ & $(1.488)$ & $(2.259)$ & $(3.433)$ & $(3.215)$ \\
$\operatorname{ResM} 2_{t-6}$ & -0.339 & -0.087 & -0.171 & 0.079 & -0.154 & -0.287 & -0.265 & -0.285 \\
& $(2.044)$ & $(0.831)$ & $(1.945)$ & $(0.532)$ & $(0.960)$ & $(2.620)$ & $(2.187)$ & $(3.023)$ \\
$\log \left(y^{P} / N\right)_{t-1}$ & -1.224 & -0.941 & -1.288 & -1.817 & -1.182 & -0.938 & -0.577 & -0.818 \\
& $(14.303)$ & $(8.154)$ & $(21.808)$ & $(35.171)$ & $(35.569)$ & $(7.378)$ & $(2.529)$ & $(26.666)$ \\
$\log R_{L}$ & 0.079 & 0.076 & 0.002 & 0.068 & 0.303 & 0.009 & -0.030 & -0.005 \\
& $(1.907)$ & $(2.423)$ & $(0.110)$ & $(2.206)$ & $(4.391)$ & $(0.257)$ & $(0.535)$ & $(0.456)$ \\
$\log y_{t-7}^{t}$ & 0.058 & 0.022 & 0.057 & 0.172 & 0.122 & 0.134 & -0.0001 & -0.039 \\
& $(0.424)$ & $(0.540)$ & $(0.866)$ & $(1.449)$ & $(1.907)$ & $(1.034)$ & $(0.001)$ & $(0.757)$ \\
Rho1 & 1.0383 & 1.8667 & 1.7176 & 1.4123 & 1.4245 & 1.1737 & 1.3967 & 1.6667 \\
Rho2 & -0.1492 & -0.8929 & -0.7971 & -0.5274 & -0.4694 & -0.2092 & -0.4666 & -0.7890 \\
$\bar{R}^{2}$ & 0.835 & 0.784 & 0.908 & 0.955 & 0.950 & 0.667 & 0.661 \\
S.E.E. & 0.0147 & 0.0086 & 0.0085 & 0.0124 & 0.0086 & 0.0136 & 0.0176 \\
D-W & 2.04 & 1.93 & 2.68 & 2.26 & 2.16 & 2.06 & 0.0040 \\
\hline
\end{tabular}

Note. ResM2 is the residual from the expected money function (see table 14.2), PD is the GNP/GDP deflator, $y^{P} / N$ is real per capita permanent income, $R_{L}$ is the long-term bond rate, and $y^{t}$ is transitory income. 
$\log$ of the reciprocal of real per capita money balances rather than simply $\log P{ }^{6}$

In table 14.2 we present the estimates of the expected money equations that we used to construct the monetary shocks. Before discussing the price equations themselves, let us briefly describe these results.

The final form of the expected money equation relates the current quarter's change in the log of M2 to lagged values of itself, lagged transitory income, lagged values of the balance of payments scaled by high-powered money, and the change in the lagged log of U.S. M2.

For all countries at least one autoregressive money term (and usually more) is statistically significant. Transitory income has the hypothesized negative sign in all except Japan and the U.K. It is significant at the 5\% level in two of the countries, Italy and the U.S., and at the $10 \%$ level in one other, the Netherlands. The balance of payments, though again of the correct sign in seven of eight cases, is significant at the 5\% level in only two, Japan and the U.K., and at the $10 \%$ level in two others, France and Italy. The lagged U.S. monetary variable is significant at the $5 \%$ level in Canada and Germany and the $10 \%$ level in France, the Netherlands, and the U.K. Tests for serial correlation of the residuals of these equations revealed no significant serial correlation in any of the eight equations.

Now let us turn to the price equations themselves. Since we found evidence of both first- and second-order autocorrelation in the price equations for all eight countries, we used GLS with a second-order correction to estimate the equations. The OLS estimates and GLS estimates based on a first-order correction are given in the appendix to this chapter. The reason for the autocorrelation is a topic we return to in the next section.?

In general, these equations fit the data reasonably well. The standard errors, other than those for the U.S. and the U.K. (40 and 176 basis points, respectively), tend to be around 100 basis points. Moreover, the coefficients are fairly consistent with prior expectations.

The coefficients of permanent income and the interest rate in these equations are both well identified, being opposite in sign from those in the money demand function. The coefficients on the lagged monetary shocks, however, are underidentified. They are a composite of the coefficient on transitory income $\beta_{2}$ from the money demand function, the price elasticity from the supply equation $\phi$, and, in the case of the lagged shock terms, the autocorrelation coefficient from the supply equation $\lambda$.

6. As Laidler (1980) has pointed out, having actual money on the right-hand side of the equation may lead to bias. Reestimating our equations with expected rather than actual money, however, produced virtually the same results.

7. The estimated equations also include transitory income lagged seven quarters, which is one more quarter than the maximum lag on the monetary shocks. In no instance is this term significant. This is consistent with the assumption implicit in our derivation of the price equation that the monetary shocks account for movements in transitory income. 


\begin{tabular}{|c|c|c|c|c|c|c|c|c|}
\hline & $\mathrm{CA}$ & FR & $\mathrm{GE}$ & IT & JA & $\mathrm{NE}$ & UK & US \\
\hline \multicolumn{9}{|l|}{ Coefficient } \\
\hline Constant & $\begin{array}{c}0.004 \\
(1.283)\end{array}$ & $\begin{array}{c}0.012 \\
(3.570)\end{array}$ & $\begin{array}{c}0.002 \\
(0.395)\end{array}$ & $\begin{array}{c}0.018 \\
(3.560)\end{array}$ & $\begin{array}{c}0.016 \\
(3.654)\end{array}$ & $\begin{array}{c}0.005 \\
(1.194)\end{array}$ & $\begin{array}{c}0.001 \\
(0.239)\end{array}$ & $\begin{array}{c}0.005 \\
(3.549)\end{array}$ \\
\hline $\log \dot{\mathrm{M}} 2_{t-1}$ & $\begin{array}{c}0.411 \\
(3.629)\end{array}$ & $\begin{array}{c}0.349 \\
(3.785)\end{array}$ & $\begin{array}{c}0.040 \\
(0.340)\end{array}$ & $\begin{array}{c}0.054 \\
(0.497)\end{array}$ & $\begin{array}{c}0.515 \\
(4.286)\end{array}$ & $\begin{array}{c}0.276 \\
(2.393)\end{array}$ & $\begin{array}{c}0.077 \\
(0.685)\end{array}$ & $\begin{array}{c}0.880 \\
(7.871)\end{array}$ \\
\hline $\log \dot{\mathrm{M}} 2_{t-2}$ & $\ldots$ & $\ldots$ & $\begin{array}{c}0.183 \\
(1.743)\end{array}$ & $\begin{array}{c}0.201 \\
(1.940)\end{array}$ & $\begin{array}{c}0.094 \\
(0.822)\end{array}$ & $\begin{array}{c}0.249 \\
(2.186)\end{array}$ & $\begin{array}{c}0.206 \\
(1.953)\end{array}$ & $\begin{array}{r}-0.352 \\
(2.419)\end{array}$ \\
\hline $\log \dot{M} 2_{t-3}$ & $\cdots$ & $\ldots$ & $\begin{array}{c}0.352 \\
(3.233)\end{array}$ & $\begin{array}{c}0.212 \\
(1.955)\end{array}$ & $\cdots$ & $\begin{array}{c}0.010 \\
(0.086)\end{array}$ & $\begin{array}{c}0.251 \\
(2.424)\end{array}$ & $\begin{array}{c}0.172 \\
(1.583)\end{array}$ \\
\hline$(\mathrm{BP} / \mathrm{MH})_{t-1}$ & $\begin{array}{c}0.023 \\
(0.665)\end{array}$ & $\cdots$ & $\begin{array}{c}0.012 \\
(0.431)\end{array}$ & $\cdots$ & $\begin{array}{c}0.036 \\
(2.027)\end{array}$ & $\begin{array}{r}-0.057 \\
(1.511)\end{array}$ & $\begin{array}{c}0.060 \\
(2.120)\end{array}$ & \\
\hline$(\mathrm{BP} / \mathrm{MH})_{t-2}$ & $\cdots$ & $\begin{array}{c}0.164 \\
(4.131)\end{array}$ & $\cdots$ & $\begin{array}{c}0.066 \\
(1.765)\end{array}$ & $\cdots$ & $\cdots$ & $\cdots$ & \\
\hline $\log y_{t-1}^{t}$ & $\begin{array}{r}-0.041 \\
(0.919)\end{array}$ & $\begin{array}{l}\cdots \\
\ldots\end{array}$ & $\begin{array}{c}-0.028 \\
(0.403)\end{array}$ & $\begin{array}{r}-0.154 \\
(3.553)\end{array}$ & $\begin{array}{c}0.008 \\
(0.695)\end{array}$ & $\begin{array}{r}-0.137 \\
(1.815)\end{array}$ & $\begin{array}{c}0.026 \\
(0.231)\end{array}$ & $\begin{array}{r}-0.050 \\
(2.602)\end{array}$ \\
\hline $\log \dot{\mathbf{M}} 2 \mathrm{US}_{\mathrm{t}-\mathrm{I}}$ & $\begin{array}{c}0.628 \\
(2.847)\end{array}$ & $\begin{array}{c}0.276 \\
(1.733)\end{array}$ & $\begin{array}{c}0.379 \\
(1.966)\end{array}$ & $\ldots$ & $\ldots$ & $\begin{array}{c}0.403 \\
(1.699)\end{array}$ & $\begin{array}{c}0.540 \\
(1.763)\end{array}$ & \\
\hline $\bar{R}^{2}$ & 0.522 & 0.351 & 0.162 & 0.275 & 0.433 & 0.211 & 0.257 & 0.617 \\
\hline S.E.E. & 0.0115 & 0.0118 & 0.0143 & 0.0099 & 0.0070 & 0.0167 & 0.0191 & 0.0052 \\
\hline D-W & 1.92 & 2.15 & 1.91 & 1.88 & 1.90 & 1.98 & 2.00 & 1.91 \\
\hline
\end{tabular}

Note. BP is the official settlements balance, $\mathrm{MH}$ is high-powered money, and $y^{\prime}$ is transitory income. A dot above a variable signifies a first difference. 
Still, we can say something about the size and sign of the shock variables. Since $\lambda$ should be positive and less than or equal to unity and since $\beta_{2}$ and $\phi$ are greater than or equal to zero, the coefficient on the contemporaneous shock variable should be negative and between zero and minus one. The lagged terms should also be negative and declining in absolute value by an exponential of $\lambda$.

In broad outline, the estimates we obtain conform to this pattern. All of the monetary shock variables have the correct sign. In every country other than Italy, the great majority are significant and they display a general tendency to decline over time. The decline, however, is not monotonic and a number of the coefficients are greater than unity-three significantly so. In addition, for each of the eight countries, tests indicated we could reject the hypothesis of a geometrically declining pattern for the coefficients of the shock terms taken as a group. ${ }^{8}$

For the most part, our estimate of the parameters of the money demand functions appear reasonable. The income elasticities-with the exception of the estimate for Italy of 1.82 - cluster about unity, ranging from a low of approximately .60 for the U.K. to a high of approximately 1.3 for Germany. The Italian income elasticity, moreover, we have reason to suspect, is biased upward by measurement error in the income series. According to Antonio Martino (1980), tax evasion has led to a systematic understatement of the rate of growth as well as the level of Italian income during this period. This downward bias in income growth, in turn, would lead to an upward bias in the income elasticity. In Britain, the introduction of Competition and Credit Controls in 1971 could conceivably produce a bias of the opposite sort. It led to the payment of more competitive rates of interest on certificates of deposit and hence a substitution into CDs from other types of commercial bank deposits. Our inability to account for this change may mean that our estimated income elasticities are therefore less than the true values.

The interest elasticities are a more mixed lot than the income elasticities. For two countries-the U.K. and the U.S.-these estimates, which are opposite in sign from the coefficients themselves, are positive. Those for the remaining six, though negative and similar in magnitude, are significantly different from zero at the .10 level or better in only four instances.

8. Our initial reaction was that these departures of our empirical estimates from the theoretical pattern reflected model misspecification due to omission of foreign price shocks from the reduced-form price equations. Misspecification of this sort might also account for the rather short lags on the shock terms we observe. In regressions reported below in which we include foreign price variables the patterns of money-shock coefficients, however, show little change. Something other than foreign prices must therefore account for these problems. 


\subsection{Implications for Money Demand}

Our estimates of the price equations provide new and reasonably consistent cross-country evidence on what we regard as two of the important unresolved questions of money demand. One is the magnitude of the parameters of the long-run money demand function, in particular, the income elasticity. The other is the speed with which the monetary sector reaches equilibrium. Studies with recent time-series data provide a disconcertingly broad range of estimates of both. Many of these, moreover, differ from what we would have expected to find a priori. Comparison of two recent papers using multicountry quarterly data samples similar to ours illustrates the problem.

In one, Samir Al-Khuri and Saleh M. Nsouli (1978) estimated money demand functions of the simple stock-adjustment genre for M1 and M2 for six of our eight countries over a sample period slightly shorter than ours. As their paper's title implies, their chief concern lay in estimating the speed of adjustment between actual and desired cash balances. Most of these estimates appear plausible: an adjustment of $30 \%$ or greater per quarter in seventeen of twenty-four instances and, for at least one formulation for each country, an adjustment in the 40-60\% range. The problem is that their estimates of long-run income elasticities make almost no sense at all. In each of their four formulations, the average of the individual-country elasticities is 0.3 or lower and the range is from slightly negative to a high of less than 0.6 .

James Boughton's (1979) study of the demand for money in seven of our eight countries (he excludes the Netherlands) produces results at the opposite end of the spectrum. His estimates of long-run income elasticities, also derived from a simple stock-adjustment model and based upon data for the period 1960-77, are a good deal higher than those of Al-Khuri and Nsouli. The mean of the elasticities for M1 is 1.27 and for $M 2$ is 1.52. Furthermore, in only four instances, M1 in the U.S., M2 in the U.K., for which no estimate could be obtained (the coefficient on the lagged dependent variable being greater than unity) and both M1 and M2 in Italy, for which the estimated elasticities are both over 2.5, are there great divergences from those averages. The difficulty is that the adjustment coefficients for all of these countries are exeedingly low-most falling below 0.15 per quarter and none being much above 0.20 .

The problem therefore is that statistically there apears to be a trade-off between the estimated values of the speed of adjustment and of the income elasticity in the simple stock-adjustment formulation. Relatively rapid speeds of adjustment can be obtained, but at the expense of extremely low income elasticities; higher income elasticities can be had but only with much slower adjustments. That trade-off, moreover, seems to be a common result with postwar data not just a peculiarity of these two studies. 
Our own belief is that the short-run adjustment is fairly rapid and the income elasticity of demand for money fairly high-close to unity, perhaps above, in these countries. Stock-adjustment speeds of between $5 \%$ and $10 \%$ per quarter, in contrast, imply that it takes somewhere between five and eleven years for $90 \%$ of the gap between money demand and money supply to be closed. In a world in which there are other financial assets, the existence of disequilibrium for that length of time is incongruous. Similarly, other bodies of data almost universally yield estimates of income elasticities considerably higher than those often obtained with postwar data. Long-term time series for the U.S. and U.K. cross-state data for the U.S., and cross-country data are all examples. In each of these instances, the estimated income elasticities range from slightly below unity to considerably above for various monetary assets."

The results we have reported conform closely with these prior beliefs. They thus stand in sharp contrast to the standard findings of studies using post-World War II time-series data. We suspect that the source of these differences is the manner in which various studies treat the adjustment process whereby actual and desired money balances are equated.

The usual way of handling the adjustment process is to specify a stock-adjustment model that entails including a lagged-dependent variable in the final estimating equation. But, as Griliches (1961) has pointed out, even if the lagged-dependent variable is appropriate, the presence of positive autocorrelation will bias the coefficient on the lagged-dependent variable upward, thus leading to the conclusion that the adjustment process is slower than it actually is. A further problem is that the lagged-dependent variable may "improve" an equation when the true structure does not include such an adjustment process if the autocorrelation of the residuals is due to some other misspecification.

Normally the stock-adjustment process is modeled as follows:

$$
M_{t}=M_{t-1}+\rho\left(M_{t}^{d}-M_{t-1}\right)+\epsilon_{t} .
$$

If $M_{t}$ is not a stationary series but rather is trend dominated, actual money balances will consistently and unrealistically lag behind desired.

As an alternative to the conventional stock-adjustment process we initially chose to define one of the following form:

$$
M_{t}=M_{t}^{d}+\rho\left(M_{t-1}-M_{t-1}^{d}\right)+\epsilon_{t} .
$$

This is equivalent to a standard first-order autoregressive process:

$$
M_{t}=M_{t}^{d}+u_{t}
$$

9. Laidler (1977) contains a summary of the long-term time-series evidence. More recent studies include Huffman and Lothian (1980), which estimates demand functions for high-powered money for the U.K. for the years 1833-1968, and Friedman and Schwartz (1982), which presents estimates for M2 for both the U.K. and U.S. for the years 18741975. Gandolfi and Lothian (1976) contains estimates from time series of cross-state data for the period 1929-68, and Lothian (1976) estimates from time series of cross-country data. 
and

$$
u_{t}=\rho u_{t-1}+\epsilon_{t} .
$$

The GLS estimates of the price equation based on this model, however, were unsatisfactory. The Durbin-Watson statistics on average were exceedingly low, suggesting a more complicated structure for the errors. For this reason we used a second-order model of the errors in the estimates we report in table 14.1. From the standpoint of the DurbinWatson statistics these equations are much more acceptable, though there is some evidence of mild negative serial correlation remaining.

The problem with these estimates is that the autoregressive pattern for the price equation appears to follow not only a second-order process but one which entails an overadjustment to last period's error and then an offsetting adjustment to this error in the next period.

The weights associated with the lagged errors in table 14.1 provide a clue as to the possible nature of the adjustment process. Since the autocorrelation correction is equivalent to a series of quasi-differencing operations on all the variables, the fact that the coefficient on the first lagged error term is equal to one plus the absolute value of the coefficient on the second lagged term suggests that the proper specification of the price equation entails a first-order correction of the first difference of the dependent and independent variables,

$$
X_{t}-(1+\rho) X_{t-1}+\rho X_{t-2},
$$

which in turn equals

$$
\left(X_{t}-X_{t-1}\right)-\rho\left(X_{t-1}-X_{t-2}\right) .
$$

What possible arguments could justify such a specification? The most obvious is that there are two types of error processes involved in our estimation. First, there are stochastic shifts that follow an essentially random walk process, for example, a shift in "tastes" or some error in measurement that affects the intercept in a once and for all fashion:

$$
\alpha_{t}=\alpha_{t-1}+v_{t},
$$

where $\alpha$ is the intercept and $v$ is the error term, which may or may not be serially correlated. There is no reason for this type of error to be adjusted away in subsequent periods. This drift means that a disturbance from level equilibrium need never be eliminated and the level of desired real money balances or correspondingly the price level will be subject to the same sort of random walk. ${ }^{10}$

10. The papers by Coats (1979) and by Hafer and Hein (1980) present results for money demand functions estimated with quarterly U.S. data that are consistent with this explanation. The authors of both papers claim that a first-differenced version of the equation is warranted. Gordon's (1980) study of longer-term U.S. inflation is similarly consistent with our findings. 
Our results also suggest that in addition to the random walk process there are other types of disturbances which are not permanent but which are autocorrelated. Thus, if there is a shock which alters the equilibrium rate of change or prices, it will gradually be eliminated, but the level of prices need not return to its original path.

For example, if the error term of equation (14.13) which describes the behavior of the intercept term of the price equation were autocorrelated and accounted for all the stochastic behavior of prices, we could write

$$
\begin{aligned}
& P_{t}=\alpha_{t}+\beta X_{t}, \\
& \alpha_{t}=\alpha_{t-1}+v_{t}, \\
& v_{t}=\rho v_{t-1}+\epsilon_{t},
\end{aligned}
$$

where $\epsilon$ is normally distributed, not serially correlated with mean zero, and $\beta X_{t}$ represents all explanatory variables. In this case, we could solve this series of equations and estimate the following:

$$
\begin{gathered}
\left(P_{t}-P_{t-1}\right)-\rho\left(P_{t-1}-P_{t-2}\right)=\beta\left[\left(X_{t}-X_{t-1}\right)\right. \\
\left.-\rho\left(X_{t-1}-X_{t-2}\right)\right] .
\end{gathered}
$$

If our interpretation of the error term is correct, the extremely large coefficients on the lagged-dependent variable and hence extremely long periods of adjustment in equations estimated in level form are the result of confusing the shorter-term adjustment process with longer-term shifts. Similarly, the very low estimated income elasticities obtained in other studies like that of Al-Khuri and Nsouli, who use a first-differenced equation and include both a lagged-dependent variable and a correction for first-order serial correlation of the disturbances in that differenced equation, also appear suspect. We conjecture that the use of both the lagged-dependent variable and the first-order autoregressive transformation is affecting both the estimates of the adjustment process and the income coefficient.

\subsection{Foreign Shocks}

The way in which international factors operate in the price equations that we have presented is through the public's expected money function. For almost all countries we have uncovered some evidence of an effect of the balance of payments or of U.S. money-sometimes both-on the domestic nominal stock of money. An international transmission mechanism of this sort is consistent with theoretical models of the specieflow type. It is not, however, consistent with the adjustment mechanism posited in the early literature of the monetary approach to the balance of payments or with the mechanisms implicit in various discussions of inter- 
national inflation that emphasize the role played by commodity and oil price shocks.

In the early monetary approach literature, the "law of one price" and international price arbitrage were key areas of emphasis. Viewed from that perspective, our price equations are misspecified.

The way in which inflation is transmitted internationally in the simplest models of this type is via price arbitrage. An increase in the inflation in the rest of the world leads to a near-instantaneous increase in domestic inflation in the small open economy subject to a regime of fixed exchange rates. This, in turn, leads to an excess demand for money in the small economy, a balance-of-payments surplus, and an increase in the domestic nominal stock of money, in that order.

One way to test whether such effects are empirically important in the context of our model is to add foreign price variables to our basic equations. If price arbitrage does provide an international link, and unless adjustment of the domestic nominal stock of money to an incipient excess supply of, or demand for, money produced by increases in price levels abroad were completed within the quarter, then these foreign price variables should enter the equations positively and significantly.

To the extent that the domestic monetary authorities prevent the adjustment of the domestic nominal supply of money to eliminate the excess supply of or demand for money, real output will vary. If the coefficients on transitory income in the demand for money function were close to unity, the addition of foreign price variables might prove to be insignificant even though they were responsible for the change in the price level and the opposite and equal change in real income. In this case, the change in real transitory income would be sufficient to offset the change in real balances due to the price shock. In our model we avoid this simultaneity problem by making transitory income endogenous and replacing its current and lagged values with current and lagged values of the monetary shock variable. ${ }^{11}$

Table 14.3 summarizes the results of including the various price-shock terms in our basic price equations. ${ }^{12}$ The most interesting of the regression estimates themselves-those for the U.S. and oil price shocks-are contained in a series of tables in the appendix to this chapter. In all instances-for each country and for each of the price shocks-we used

11. Darby in chapter 8 of this volume contains a more complete theoretical discussion of the impact of oil prices on the overall price level.

12. As measures of the relative price of oil, we used the ratio of the dollar price of Venezuelan crude to either the U.S. CPI or GNP deflator. As measures of commodity prices, we used the ratio of the London Economist's dollar-based index of commodity to either the U.S. CPI or GNP deffator. For each country, we calculated separate rest-of-world indices of the CPIs or deflators as nominal-income weighted averages of the indices for the seven foreign countries. 


\begin{tabular}{|c|c|c|c|c|c|c|c|c|}
\hline \multirow[b]{2}{*}{ Country } & \multicolumn{4}{|c|}{ GNP/GDP Deflator } & \multicolumn{4}{|c|}{ CPI/Cost of Living } \\
\hline & $\begin{array}{l}\text { Relative } \\
\text { Price of } \\
\text { Oil }\end{array}$ & $\begin{array}{l}\text { World } \\
\text { Commodity } \\
\text { Price Index }\end{array}$ & $\begin{array}{l}\text { U.S. } \\
\text { Defiator }\end{array}$ & $\begin{array}{l}\text { Rest-of- } \\
\text { World } \\
\text { Deflator }\end{array}$ & $\begin{array}{l}\text { Relative } \\
\text { Price of } \\
\text { Oil }\end{array}$ & $\begin{array}{l}\text { World } \\
\text { Commodity } \\
\text { Price Index }\end{array}$ & $\begin{array}{l}\text { U.S. } \\
\text { CPI }\end{array}$ & $\begin{array}{l}\text { Rest-of- } \\
\text { World } \\
\text { CPI }\end{array}$ \\
\hline $\mathrm{CA}$ & $\dagger$ & $\dagger, \S$ & $\ldots$ & $\ldots$ & $\ldots$ & $\ldots$ & $\ldots$ & $\ldots$ \\
\hline FR & $\ldots$ & $\ldots$ & $\ldots$ & $\dagger, \S$ & $\doteqdot, \S$ & $\cdots$ & $\ldots$ & $\dagger, \S$ \\
\hline GE & $\S$ & $\ldots$ & $\ldots$ & $\ldots$ & $\ldots$ & $\ldots$ & $\ldots$ & $\ldots$ \\
\hline IT & $\ldots$ & $\dagger$ & $\ldots$ & $\ldots$ & $\dagger, \S$ & $\dagger, \S$ & $\ldots$ & $\S$ \\
\hline $\mathrm{JA}$ & $\dagger, \S$ & $\ldots$ & $\S$ & $\dagger$ & $\dagger, \S$ & $\cdots$ & $\dagger, \S$ & $\dagger, \S$ \\
\hline $\mathrm{NE}$ & $\ldots$ & $\ldots$ & $\ldots$ & $\ldots$ & $\ldots$ & $\ldots$ & $\cdots$ & $\ldots$ \\
\hline UK & $\dagger, \S$ & $\ldots$ & $\S$ & $\dagger$ & $\ldots$ & $\ldots$ & $t$ & $\dagger$ \\
\hline US & $\dagger$ & $\dagger$ & $\cdots$ & $\cdots$ & $\dagger, \S$ & $\cdots$ & $\cdots$ & $\cdots$ \\
\hline \multicolumn{9}{|c|}{ Number of Countries for Which Foreign Shock is Significant } \\
\hline First order & 4 & 3 & $\ldots$ & 3 & 4 & 1 & 2 & 3 \\
\hline Second order & 3 & 1 & 2 & 1 & 4 & 1 & 1 & 3 \\
\hline
\end{tabular}

Note. Variables are as defined in text.

${ }^{+}$Significant $F$ statistics at $10 \%$ or better in equation with a correction for first-order autocorrelation.

${ }^{\S}$ Significant $F$ statistics at $10 \%$ or better in equation with a correction for second-order autocorrelation. 
two measures of the domestic price level: the CPI or other cost of living index as well as the GNP or GDP deflator that we used in the regressions summarized above. Again we estimated these equations via GLS.

In virtually every case, we again had to use a second-order autoregressive model of the disturbances before we found no evidence of significant autocorrelation. That in and of itself is a finding of some interest since a possible explanation for the findings reported above is that foreign price shocks were omitted from the regressions. Such shocks conceivably could be responsible for the apparent random walk process we have uncovered.

Our finding of little difference in the error process after inclusion of the price shocks in the regressions, however, does not support that hypothesis. Either something else is responsible, or our price-shock measures are highly imperfect proxies for the true shocks. The latter, however, does not seem to be the case-at least with respect to oil and other commodity price shocks. Estimating the basic equations over shorter periods in which such shocks might be considered of little importance produced in general, no substantial changes in our estimates of the error process.

Now let us consider the test results, first those for the U.S. and rest-of-world price variables. Here the evidence is quite mixed. Only for Japan and the U.K. are both of the U.S. price variables significantly greater than zero at a level of $10 \%$ or better. Rest-of-world prices are significant for France, Japan, and the U.K. in both the deflator and the CPI regressions, and for Italy in the CPI regression. Some evidence of price arbitrage therefore exists, but even on the most favorable interpretation of the evidence it is weak and hardly universal. Canada, Germany, and the Netherlands (relative to both measures of rest-of-world prices) show little or no such effects, and Italy an inconsistent effect. In most instances, moreover, the bulk of the effects show up after a lag of two quarters or more.

Commodity prices in general do not fare well at all in the test of price-shock effects. The London Economist index of commodity prices is only significant in four of the sixteen comparisons.

The variable that appears to have the most persistent influence is the relative price of oil. With the deflator as the measure of the price level, the oil price variable is significant at a level of $10 \%$ or better in five countries: Canada, Germany, Japan, the U.K., and the U.S. In one other, France, the effect was nearly significant. Using the CPI, we found significant effects for Japan again as well as for France and Italy.

Table 14.4 contains alternative estimates of the magnitude of these effects on both measures of the price level for all of the countries other than the Netherlands. We omitted the Netherlands because its coefficients were consistently negative, a problem to which we return below.

These estimates are for two periods, 1973I to 1974IV and 1973I to 
Table 14.4

Contribution of Changes in Relative Oil Prices

to Domestic Price Levels

\begin{tabular}{|c|c|c|c|c|}
\hline \multirow[b]{3}{*}{ Country } & \multicolumn{4}{|c|}{ GNP/GDP Deflator } \\
\hline & \multicolumn{2}{|c|}{ 1973I-74IV } & \multicolumn{2}{|c|}{$1973 \mathrm{I}-76 \mathrm{IV}$} \\
\hline & GLS1 & GLS2 & GLS1 & GLS2 \\
\hline $\mathrm{CA}$ & 28.8 & 29.2 & 15.5 & 15.7 \\
\hline FR & 51.9 & 23.5 & 25.0 & 11.2 \\
\hline GE & 17.9 & 14.9 & 11.1 & 9.2 \\
\hline IT & 21.9 & -4.6 & 12.5 & -2.7 \\
\hline JA & 25.9 & 31.0 & 18.2 & 21.8 \\
\hline UK & 7.3 & 4.0 & 3.3 & 1.8 \\
\hline US & 24.5 & 4.1 & 14.2 & 2.4 \\
\hline \multicolumn{5}{|c|}{ CPI/Cost of Living } \\
\hline CA & 17.0 & -38.4 & 9.0 & -20.4 \\
\hline FR & 58.1 & 52.2 & 30.1 & 27.0 \\
\hline GE & 9.3 & -10.0 & 5.7 & 6.1 \\
\hline IT & 28.1 & 10.4 & 14.2 & 5.1 \\
\hline $\mathrm{JA}$ & 34.5 & 43.0 & 23.3 & 29.0 \\
\hline UK & -8.8 & -21.5 & -3.5 & -8.6 \\
\hline US & 27.6 & 12.5 & 16.4 & 7.4 \\
\hline
\end{tabular}

Note. The above figures are the ratio of (1) the product of the change in logarithm of the relative price of oil over the appropriate period and the sum of the oil price coefficients in the relevant regression to (2) the change in the logarithm of the relevant domestic price index. The symbol GLS1 denotes a regression with a correction for first-order autocorrelation; GLS2, a regression with a correction of second-order autocorrelation.

1976IV, and for both the CPI and deflator measures of the price level. To derive them we first multiplied the ratio of the annualized change in the logarithm of the relative price of oil by the sum of the oil price coefficients in the relevant regression. We then divided that product by the annualized change in the logarithm of the price level.

With relatively few exceptions, the ratios for the deflator fall in a range of roughly $5 \%$ to $30 \%$. These ratios moreover tend to decrease with the length of the time period and the complexity of the error model used in the underlying regressions. The median ratio for the period ending in $1974 \mathrm{IV}$ is $24.5 \%$ in the regressions with a first-order correction and $14.9 \%$ in those with a second-order regression. For the longer period, the median ratios are $14.2 \%$ and $9.2 \%$ from the two types of regressions respectively.

The median ratios for the CPI exhibit the same general pattern: $27.6 \%$ and $10.4 \%$ for the period ending $1974 \mathrm{IV}$ and $14.2 \%$ and $6.1 \%$ for the period ending $1976 \mathrm{IV}$ in the two types of regressions.

Comparison of these estimates with those reported in a recent study by Phillip Cagan (1980) of manufacturing industries in the United States 
may prove interesting. Cagan estimates that approximately $15 \%$ of the $17.0 \%$ annual average rate of increase of manufacturing prices in 197274 , or about 2.6 percentage points, can be accounted for in terms of increases in oil prices. Our own estimates are for the shorter 1973-74 period and for price indices that place less weight on traded goods. Their range is from approximately equal to Cagan's to considerably below..$^{13}$

The estimate derived from the regressions with a first-order correction are $24.5 \%$ of the increase in the deflator and $27.6 \%$ of the increase in the CPI, or 2.1 and 2.5 percentage points respectively. Those derived from the regressions with a second-order correction are a good deal lower: $4.1 \%$ of the deflator increase ( 0.3 percentage points) and $12.5 \%$ of the CPI increase (or 1.12 percentage points).

There are, however, a number of problems with our results that lead us to question how seriously they can be taken. The most obvious is the negative coefficients obtained in a considerable number of cases: Canada, Italy, Germany, and the U.K. for at least one price variable and one type of regression, and the Netherlands, as we have already stated, for both price variables and both types of regressions.

For the deflator, which is based upon value added production, negative effects are possible but over periods of several years somewhat implausible. For the CPI, which is an index of prices in consumption, negative estimates for countries that do not produce petroleum make little sense.

That difference in what the two price indices measure raises an additional question. Even if we ignore the greater incidence of negative sums of coefficients with the CPI on the grounds that the use of the secondorder correction may be unduly influencing the results, the CPI fares no better than the deflator. We would have expected exactly the opposite. Indeed that was the main reason we reestimated the price equations using the CPI in place of the deflator, the price variable we used in developing the basic model.

Equally disturbing is the lack of consistency in results for the two indices. Only for Japan do we obtain significant positive effects with both price measures and both types of regressions.

A further problem, as Michael Darby has pointed out in chapter 8 , is that in a number of countries the removal of price controls occurred more or less coincidentally with the rise in oil prices. Separating these effects from those of oil prices on the price level is virtually impossible.

\subsection{Summary and Conclusions}

Starting with a conventional money demand function, a Lucas-type aggregate supply function, and a general form of the public's expected

13. There is a further difference between Cagan's (1980) and our estimates. What Cagan is measuring is impact effects. Our estimates, in contrast, implicitly allow for subsequent adjustment of the relative prices of other products. 
money function, we have derived a reduced-form price equation that we have estimated with quarterly data for the United States and seven other industrial countries for a near twenty-year period beginning in the late 1950s. We have then gone on to use these equations to test a variety of hypotheses about the international inflation process during these years.

The equations themselves fit the data fairly well. Moreover, the parameter estimates we obtain are both reasonably consistent across countries and tolerably close to our prior expectations of magnitude and, in the case of the monetary shocks, temporal pattern. We therefore have confidence in using the equations as a basis for testing competing hypotheses.

The principal conclusion that emerges from this exercise is that movements in domestic money in all eight countries serve as the key link in the process leading to changes in the domestic rates of inflation. The factors that produced changes in the domestic money shocks, however, differed among countries. In the seven foreign countries, international factorsthe balance of payments or United States money, in some instances both-had some influence in the expected money equations; in the United States, the reserve-currency country, they did not.

Foreign rates of inflation, as measured by either United States inflation or a rest-of-world inflation index, however, had a direct impact on domestic rates of inflation in relatively few of the comparisons we made. To the extent that inflation was actually transmitted from one country to another, it appears to have been via channels much closer to a specie-flow type of mechanism than to the price-arbitrage mechanism. ${ }^{14}$

These findings therefore point to the short-run possibility of monetary control. Other evidence, namely that foreign factors by no means predominate in terms of explainability in the expected money equations, add to this impression.

The other factor that may have had an influence upon domestic inflation rates in these countries is increases in the relative price of oil. The extent of the influence, though, is not easily ascertainable from our comparisons. Viewed in terms of the results most favorable to the hypothesis, the regressions with the corrections for first-order autocorrelation, the oil price impact accounted for a substantial, but in most countries far from major, proportion of the inflation over the 1973-74 period. Viewed on the basis of the regressions with the second-order correction, the effects are in general of considerably less magnitude and may in fact be largely spurious.

14. The two are not competing hypotheses. Both channels of transmission in principle can operate at the same time. The key question is the quantitative importance of the one vis-à-vis the other within the relevant time period.

It is also important to note that our results are for measured price indices. Aggregation as well as measurement error may obscure the effects of price arbitrage in individual markets. 
The other major area requiring some additional discussion is the demand for money. We find that in all of these countries the rate of inflation rather than level of prices is uniquely determined. This is consistent with a number of other pieces of evidence. Our study using time series of cross-state data, the Huffman and Lothian (1980) paper on the United Kingdom, and several studies based upon time-series data for the United States are all examples. ${ }^{15}$

The cause of these stochastic shifts, however, so far has not been determined. Measurement error in either prices, real income, or money is a possibility. Omitted variables in the money demand function-the change in "financial sophistication" used by Friedman and Schwartz (1982) or the similar variable used by Bordo and Jonung in their longterm time-series study-is another. Further investigation of this question is clearly of considerable importance. Our results suggest, however, that the explanation will have to be applicable to more countries than just the United States.

\section{Acknowledgments}

The authors would like to acknowledge the able research assistance of Connie McCarthy and the helpful comments of Michael R. Darby, Anna J. Schwartz, Alan C. Stockman, and the members of the monetary workshops at Columbia University and of the Graduate School of Business at New York University.

15. See the studies cited above in footnote 9. 


\section{Appendix}

\section{International Price Behavior and the Demand for Money}

Table 14.5A Price Equation with Dependent Variable $\log \mathrm{PD}-\log (\mathrm{M} 2 / N)$, 1957III to 1976IV (absolute value of $t$ statistic in parentheses)

\begin{tabular}{ccccccccc}
\hline & CA & FR & GE & IT & JA & NE & UK & US \\
\hline Coefficient & & & & & & & & \\
Constant & 2.774 & 5.834 & 5.087 & 11.837 & 5.307 & 1.706 & -0.109 & -0.967 \\
& $(3.829)$ & $(6.484)$ & $(9.830)$ & $(39.380)$ & $(29.060)$ & $(2.763)$ & $(0.099)$ & $(1.409)$ \\
ResM2 $t$ & -0.148 & 0.485 & -0.722 & -0.731 & -0.552 & -0.233 & -0.904 & -0.927 \\
& $(0.378)$ & $(0.655)$ & $(2.331)$ & $(2.126)$ & $(1.321)$ & $(0.898)$ & $(2.751)$ & $(2.311)$ \\
ResM2 $2_{t-1}$ & -1.032 & -0.103 & -0.619 & -0.644 & -0.595 & -0.389 & -0.861 & -1.963 \\
& $(2.697)$ & $(0.152)$ & $(1.989)$ & $(1.847)$ & $(1.405)$ & $(1.521)$ & $(2.612)$ & $(5.239)$ \\
ResM2 $_{t-2}$ & -1.117 & 0.030 & -0.366 & -0.554 & -0.934 & -0.553 & -1.119 & -2.158 \\
& $(3.035)$ & $(0.046)$ & $(1.203)$ & $(1.627)$ & $(2.212)$ & $(2.184)$ & $(3.279)$ & $(6.056)$ \\
ResM2 $_{t-3}$ & -0.991 & 0.113 & -0.696 & -0.590 & -0.791 & -0.294 & -1.292 & -1.889 \\
& $(3.022)$ & $(0.169)$ & $(2.254)$ & $(1.708)$ & $(2.209)$ & $(1.240)$ & $(4.085)$ & $(5.411)$
\end{tabular}




\begin{tabular}{lcccccccc}
$\operatorname{ResM} 2_{t-4}$ & -0.765 & -0.037 & -0.428 & -0.504 & -0.593 & -0.023 & -1.254 & -1.704 \\
& $(2.050)$ & $(0.054)$ & $(1.336)$ & $(1.450)$ & $(1.441)$ & $(0.094)$ & $(3.876)$ & $(4.721)$ \\
$\operatorname{ResM} 2_{t-5}$ & -1.345 & 0.479 & -0.790 & -0.538 & -0.410 & -0.071 & -1.226 & -1.580 \\
& $(3.678)$ & $(0.674)$ & $(2.189)$ & $(1.548)$ & $(1.007)$ & $(0.286)$ & $(3.692)$ & $(4.291)$ \\
$\operatorname{ResM} 2_{t-6}$ & -0.934 & -0.299 & -1.274 & -0.121 & -0.554 & -0.123 & -1.025 & -1.496 \\
& $(2.581)$ & $(0.377)$ & $(3.579)$ & $(0.347)$ & $(1.392)$ & $(0.454)$ & $(3.116)$ & $(4.325)$ \\
$\log \left(y^{P} / N\right)_{t-1}$ & -1.185 & -1.375 & -1.386 & -1.810 & -1.213 & -1.029 & -0.836 & -0.785 \\
& $(16.332)$ & $(17.870)$ & $(31.148)$ & $(94.312)$ & $(165.900)$ & $(18.355)$ & $(5.735)$ & $(11.556)$ \\
$\log R_{L}$ & 0.077 & 0.479 & 0.023 & 0.137 & 0.828 & 0.104 & 0.026 & -0.008 \\
& $(1.513)$ & $(6.460)$ & $(0.463)$ & $(6.701)$ & $(17.128)$ & $(2.394)$ & $(0.475)$ & $(0.201)$ \\
$\log y_{t-7}^{t}$ & 0.119 & -0.784 & 0.878 & 1.008 & 0.131 & 1.247 & -0.566 & 0.090 \\
$\bar{R}^{2}$ & $(0.759)$ & $(2.123)$ & $(4.203)$ & $(5.543)$ & $(2.386)$ & $(6.673)$ & $(1.397)$ & $(1.278)$ \\
S.E.E. & 0.982 & 0.952 & 0.981 & 0.996 & 0.999 & 0.968 & 0.849 \\
D-W & 0.0306 & 0.0661 & 0.0354 & 0.0287 & 0.0202 & 0.0332 & 0.0513 \\
\hline Note. Var & 0.32 & 0.21 & 0.41 & 0.30 & 0.34 & 0.45 & 0.083 \\
\hline
\end{tabular}

Note. Variables are defined as in table 14.1. 
Table 14.5B Price Equation with Dependent Variable $\log \mathrm{PD}-\log (\mathrm{M} 2 / N)$, 1957III to 1976IV (absolute value of $t$ statistic in parentheses)

\begin{tabular}{|c|c|c|c|c|c|c|c|c|}
\hline & $\mathrm{CA}$ & FR & GE & IT & $\mathrm{JA}$ & $\mathrm{NE}$ & UK & US \\
\hline \multicolumn{9}{|l|}{ Coefficient } \\
\hline Constant & $\begin{array}{c}3.178 \\
(3.856)\end{array}$ & $\begin{array}{c}0.703 \\
(0.619)\end{array}$ & $\begin{array}{c}3.640 \\
(3.553)\end{array}$ & $\begin{array}{c}12.477 \\
(12.279)\end{array}$ & $\begin{array}{c}3.895 \\
(7.717)\end{array}$ & $\begin{array}{c}0.731 \\
(0.639)\end{array}$ & $\begin{array}{c}-3.800 \\
(1.817)\end{array}$ & $\begin{array}{c}-1.371 \\
(2.389)\end{array}$ \\
\hline $\operatorname{ResM} 2_{t}$ & $\begin{array}{c}-0.465 \\
(2.658)\end{array}$ & $\begin{array}{c}-0.983 \\
(5.693)\end{array}$ & $\begin{array}{c}-0.841 \\
(7.751)\end{array}$ & $\begin{array}{c}-0.716 \\
(4.336)\end{array}$ & $\begin{array}{c}-0.944 \\
(5.160)\end{array}$ & $\begin{array}{c}-0.841 \\
(8.059)\end{array}$ & $\begin{array}{c}-0.968 \\
(8.644)\end{array}$ & $\begin{array}{c}-0.942 \\
(6.815)\end{array}$ \\
\hline $\operatorname{ResM} 2_{t-1}$ & $\begin{array}{c}-1.063 \\
(4.940)\end{array}$ & $\begin{array}{c}-1.145 \\
(4.698)\end{array}$ & $\begin{array}{c}-0.560 \\
(3.944)\end{array}$ & $\begin{array}{c}-0.571 \\
(2.669)\end{array}$ & $\begin{array}{c}-1.086 \\
(4.508)\end{array}$ & $\begin{array}{c}-0.818 \\
(6.490)\end{array}$ & $\begin{array}{c}-0.804 \\
(5.663)\end{array}$ & $\begin{array}{c}-1.698 \\
(10.111)\end{array}$ \\
\hline $\operatorname{Res} M 2_{t-2}$ & $\begin{array}{c}-0.842 \\
(3.889)\end{array}$ & $\begin{array}{c}-0.874 \\
(3.451)\end{array}$ & $\begin{array}{c}-0.411 \\
(2.685)\end{array}$ & $\begin{array}{c}-0.474 \\
(2.043)\end{array}$ & $\begin{array}{c}-1.138 \\
(4.832)\end{array}$ & $\begin{array}{c}-0.818 \\
(6.288)\end{array}$ & $\begin{array}{c}-0.703 \\
(4.679)\end{array}$ & $\begin{array}{c}-1.759 \\
(9.690)\end{array}$ \\
\hline $\operatorname{ResM} 2_{t-3}$ & $\begin{array}{c}-0.886 \\
(4.584)\end{array}$ & $\begin{array}{c}-0.584 \\
(2.272)\end{array}$ & $\begin{array}{c}-0.492 \\
(3.073)\end{array}$ & $\begin{array}{c}-0.339 \\
(1.444)\end{array}$ & $\begin{array}{c}-1.058 \\
(5.275)\end{array}$ & $\begin{array}{c}-0.605 \\
(4.747)\end{array}$ & $\begin{array}{c}-0.931 \\
(6.412)\end{array}$ & $\begin{array}{c}-1.464 \\
(8.107)\end{array}$ \\
\hline $\operatorname{ResM} 2_{t-4}$ & $\begin{array}{c}-0.688 \\
(3.256)\end{array}$ & $\begin{array}{c}-0.485 \\
(1.871)\end{array}$ & $\begin{array}{c}-0.344 \\
(2.205)\end{array}$ & $\begin{array}{c}-0.214 \\
(0.931)\end{array}$ & $\begin{array}{c}-0.920 \\
(4.045)\end{array}$ & $\begin{array}{c}-0.515 \\
(3.625)\end{array}$ & $\begin{array}{c}-0.757 \\
(5.074)\end{array}$ & $\begin{array}{c}-1.113 \\
(6.079)\end{array}$ \\
\hline
\end{tabular}




\begin{tabular}{lcccccccc} 
ResM2 & -0.948 & -0.291 & -0.220 & -0.240 & -0.473 & -0.335 & -0.660 & -0.857 \\
& $(4.550)$ & $(1.152)$ & $(1.398)$ & $(1.145)$ & $(2.145)$ & $(2.441)$ & $(4.549)$ & $(4.985)$ \\
$\operatorname{ResM} 2_{t-6}$ & -0.337 & -0.198 & -0.223 & 0.028 & -0.235 & -0.287 & -0.368 & -0.522 \\
& $(2.032)$ & $(1.104)$ & $(1.689)$ & $(0.177)$ & $(1.357)$ & $(2.588)$ & $(3.041)$ & $(3.933)$ \\
$\log \left(y^{P} / N\right)_{t-1}$ & -1.232 & -0.928 & -1.234 & -1.863 & -1.181 & -0.953 & -0.318 & -0.738 \\
& $(13.405)$ & $(7.828)$ & $(11.239)$ & $(25.891)$ & $(34.760)$ & $(7.678)$ & $(1.037)$ & $(11.426)$ \\
$\log R_{L}$ & 0.086 & 0.128 & 0.0003 & 0.106 & 0.441 & 0.005 & -0.098 & -0.009 \\
& $(2.096)$ & $(2.389)$ & $(0.011)$ & $(3.316)$ & $(6.281)$ & $(0.131)$ & $(1.735)$ & $(0.479)$ \\
$\log y_{t-1}^{t}$ & 0.105 & -0.068 & 0.220 & 0.454 & 0.158 & 0.151 & 0.097 & 0.174 \\
& $(0.735)$ & $(0.667)$ & $(1.660)$ & $(3.221)$ & $(2.241)$ & $(1.134)$ & $(0.545)$ & $(2.575)$ \\
Rho1 & 0.9102 & 0.9884 & 0.9714 & 0.9410 & 0.9694 & 0.9704 & 0.9767 & 0.9508 \\
$\bar{R}^{2}$ & 0.804 & 0.554 & 0.692 & 0.912 & 0.954 & 0.672 & 0.540 \\
S.E.E. & 0.0148 & 0.0154 & 0.0130 & 0.0137 & 0.0093 & 0.0139 & 0.0193 \\
D-W & 1.77 & 0.52 & 0.71 & 1.34 & 1.36 & 1.63 & 0.814 \\
\hline
\end{tabular}

Note. Variables are defined as in table 14.1. 
Table 14.6A Price Equation with Dependent Variable $\log \mathrm{PD}-\log (\mathrm{M} 2 / N)$, $1957 \mathrm{III}$ to 1976IV (absolute value of $t$ statistics in parentheses)

\begin{tabular}{|c|c|c|c|c|c|c|c|}
\hline & $\mathrm{CA}$ & FR & GE & IT & JA & $\mathrm{NE}$ & UK \\
\hline \multicolumn{8}{|l|}{ Coefficient } \\
\hline Constant & $\begin{array}{c}2.361 \\
(1.246)\end{array}$ & $\begin{array}{c}4.193 \\
(2.349)\end{array}$ & $\begin{array}{c}5.788 \\
(3.602)\end{array}$ & $\begin{array}{c}12.854 \\
(10.681)\end{array}$ & $\begin{array}{c}5.768 \\
(13.300)\end{array}$ & $\begin{array}{c}-1.520 \\
(0.586)\end{array}$ & $\begin{array}{c}6.287 \\
(2.483)\end{array}$ \\
\hline $\operatorname{ResM} 2_{t}$ & $\begin{array}{c}-0.671 \\
(5.928)\end{array}$ & $\begin{array}{c}-1.011 \\
(5.766)\end{array}$ & $\begin{array}{c}-0.846 \\
(8.060)\end{array}$ & $\begin{array}{c}-0.732 \\
(5.455)\end{array}$ & $\begin{array}{c}-0.887 \\
(4.102)\end{array}$ & $\begin{array}{c}-0.867 \\
(8.322)\end{array}$ & $\begin{array}{l}-0.852 \\
(10.078)\end{array}$ \\
\hline $\operatorname{ResM} 2_{t-1}$ & $\begin{array}{c}-0.824 \\
(5.681)\end{array}$ & $\begin{array}{c}-1.284 \\
(5.312)\end{array}$ & $\begin{array}{c}-0.556 \\
(4.185)\end{array}$ & $\begin{array}{c}-0.653 \\
(3.736)\end{array}$ & $\begin{array}{c}-1.223 \\
(4.357)\end{array}$ & $\begin{array}{c}-0.882 \\
(6.972)\end{array}$ & $\begin{array}{c}-0.714 \\
(6.727)\end{array}$ \\
\hline $\operatorname{ResM} 2_{t-2}$ & $\begin{array}{c}-0.790 \\
(5.528)\end{array}$ & $\begin{array}{c}-1.128 \\
(4.559)\end{array}$ & $\begin{array}{c}-0.435 \\
(3.048)\end{array}$ & $\begin{array}{c}-0.776 \\
(4.113)\end{array}$ & $\begin{array}{c}-1.290 \\
(4.656)\end{array}$ & $\begin{array}{c}-0.983 \\
(7.548)\end{array}$ & $\begin{array}{c}-0.679 \\
(6.133)\end{array}$ \\
\hline $\operatorname{ResM} 2_{t-3}$ & $\begin{array}{c}-0.859 \\
(6.762)\end{array}$ & $\begin{array}{c}-0.887 \\
(3.523)\end{array}$ & $\begin{array}{c}-0.556 \\
(3.704)\end{array}$ & $\begin{array}{c}-0.679 \\
(3.604)\end{array}$ & $\begin{array}{c}-1.094 \\
(4.641)\end{array}$ & $\begin{array}{c}-0.724 \\
(5.649)\end{array}$ & $\begin{array}{c}-0.677 \\
(6.417)\end{array}$ \\
\hline $\operatorname{Res} M 2_{t-4}$ & $\begin{array}{c}-0.736 \\
(5.249)\end{array}$ & $\begin{array}{c}-0.791 \\
(3.104)\end{array}$ & $\begin{array}{c}-0.344 \\
(2.358)\end{array}$ & $\begin{array}{c}-0.494 \\
(2.694)\end{array}$ & $\begin{array}{c}-1.237 \\
(4.609)\end{array}$ & $\begin{array}{c}-0.649 \\
(4.551)\end{array}$ & $\begin{array}{r}-0.540 \\
(4.897)\end{array}$ \\
\hline $\operatorname{ResM} 2_{t-5}$ & $\begin{array}{c}-0.557 \\
(4.068)\end{array}$ & $\begin{array}{c}-0.591 \\
(2.352)\end{array}$ & $\begin{array}{c}-0.295 \\
(1.988)\end{array}$ & $\begin{array}{r}-0.267 \\
(1.601)\end{array}$ & $\begin{array}{c}-0.712 \\
(2.759)\end{array}$ & $\begin{array}{c}-0.516 \\
(3.732)\end{array}$ & $\begin{array}{c}-0.400 \\
(3.779)\end{array}$ \\
\hline $\operatorname{ResM} 2_{t-6}$ & $\begin{array}{c}-0.236 \\
(2.151)\end{array}$ & $\begin{array}{c}-0.386 \\
(2.178)\end{array}$ & $\begin{array}{c}-0.223 \\
(1.779)\end{array}$ & $\begin{array}{c}-0.093 \\
(0.711)\end{array}$ & $\begin{array}{c}-0.516 \\
(2.511)\end{array}$ & $\begin{array}{c}-0.349 \\
(3.150)\end{array}$ & $\begin{array}{c}-0.201 \\
(2.300)\end{array}$ \\
\hline
\end{tabular}




\begin{tabular}{|c|c|c|c|c|c|c|c|}
\hline $\log \left(y^{P} / N\right)_{t-1}$ & $\begin{array}{c}-1.173 \\
(5.108)\end{array}$ & $\begin{array}{c}-1.325 \\
(6.852)\end{array}$ & $\begin{array}{c}-1.453 \\
(8.408)\end{array}$ & $\begin{array}{c}1.887 \\
(21.114)\end{array}$ & $\begin{array}{l}-1.327 \\
(36.887)\end{array}$ & $\begin{array}{c}-0.684 \\
(2.381)\end{array}$ & $\begin{array}{c}-1.812 \\
(4.745)\end{array}$ \\
\hline $\log R_{L}$ & $\begin{array}{c}-0.010 \\
(0.370)\end{array}$ & $\begin{array}{c}0.047 \\
(0.729)\end{array}$ & $\begin{array}{c}0.041 \\
(1.381)\end{array}$ & $\begin{array}{c}0.127 \\
(4.253)\end{array}$ & $\begin{array}{c}0.421 \\
(4.494)\end{array}$ & $\begin{array}{c}0.042 \\
(1.116)\end{array}$ & $\begin{array}{c}-0.019 \\
(0.420)\end{array}$ \\
\hline $\log y_{t-1}^{t}$ & $\begin{array}{c}0.076 \\
(0.801)\end{array}$ & $\begin{array}{c}-0.106 \\
(1.066)\end{array}$ & $\begin{array}{c}0.054 \\
(0.425)\end{array}$ & $\begin{array}{c}0.145 \\
(1.268)\end{array}$ & $\begin{array}{c}0.110 \\
(1.438)\end{array}$ & $\begin{array}{c}-0.064 \\
(0.476)\end{array}$ & $\begin{array}{c}0.038 \\
(0.292)\end{array}$ \\
\hline $\log \mathrm{USPC}_{r}$ & $\begin{array}{c}0.882 \\
(2.187)\end{array}$ & $\begin{array}{c}0.566 \\
(0.842)\end{array}$ & $\begin{array}{c}-0.179 \\
(0.373)\end{array}$ & $\begin{array}{c}0.174 \\
(0.403)\end{array}$ & $\begin{array}{c}0.655 \\
(1.341)\end{array}$ & $\begin{array}{c}-0.082 \\
(0.149)\end{array}$ & $\begin{array}{c}-1.574 \\
(2.711)\end{array}$ \\
\hline $\log \mathrm{USPC}_{t-1}$ & $\begin{array}{c}0.064 \\
(0.139)\end{array}$ & $\begin{array}{c}0.644 \\
(0.878)\end{array}$ & $\begin{array}{c}-0.192 \\
(0.344)\end{array}$ & $\begin{array}{c}0.908 \\
(1.726)\end{array}$ & $\begin{array}{c}-0.168 \\
(0.273)\end{array}$ & $\begin{array}{c}-0.527 \\
(0.832)\end{array}$ & $\begin{array}{c}0.295 \\
(0.440)\end{array}$ \\
\hline $\log \mathrm{USPC}_{t-2}$ & $\begin{array}{c}-0.178 \\
(0.390)\end{array}$ & $\begin{array}{c}0.328 \\
(0.426)\end{array}$ & $\begin{array}{c}-0.088 \\
(0.139)\end{array}$ & $\begin{array}{c}-0.365 \\
(0.702)\end{array}$ & $\begin{array}{c}0.236 \\
(0.390)\end{array}$ & $\begin{array}{c}-0.749 \\
(1.158)\end{array}$ & $\begin{array}{c}0.745 \\
(1.126)\end{array}$ \\
\hline $\log \mathrm{USPC}_{t-3}$ & $\begin{array}{c}-0.774 \\
(2.074)\end{array}$ & $\begin{array}{c}-0.869 \\
(1.442)\end{array}$ & $\begin{array}{c}0.462 \\
(0.982)\end{array}$ & $\begin{array}{c}-0.813 \\
(1.929)\end{array}$ & $\begin{array}{c}-0.181 \\
(0.384)\end{array}$ & $\begin{array}{c}0.918 \\
(1.764)\end{array}$ & $\begin{array}{c}1.388 \\
(2.418)\end{array}$ \\
\hline Rhol & 0.9889 & 0.9893 & 0.9678 & 0.8936 & 0.8451 & 0.9801 & 0.9799 \\
\hline $\bar{R}^{2}$ & 0.734 & 0.558 & 0.779 & 0.973 & 0.990 & 0.695 & 0.673 \\
\hline S.E.E. & 0.0099 & 0.0146 & 0.0119 & 0.0107 & 0.0104 & 0.0137 & 0.0138 \\
\hline D.W & 0.80 & 0.62 & 0.98 & 1.10 & 1.62 & 1.61 & 0.75 \\
\hline
\end{tabular}

Note. USPC is the U.S. consumer price index; the other variables are as defined in table 14.1. 
Price Equation with Dependent Variable $\log \mathrm{PD}-\log (\mathrm{M} 2 / N)$, 1957III to $1976 \mathrm{IV}$ (absolute value of $t$ statistic in parentheses)

\begin{tabular}{|c|c|c|c|c|c|c|c|}
\hline & $\mathrm{CA}$ & FR & GE & IT & JA & $\mathrm{NE}$ & UK \\
\hline \multicolumn{8}{|l|}{ Coefficient } \\
\hline Constant & $\begin{array}{c}-1.107 \\
(1.686)\end{array}$ & $\begin{array}{c}-3.179 \\
(0.912)\end{array}$ & $\begin{array}{c}2.989 \\
(1.847)\end{array}$ & $\begin{array}{c}13.045 \\
(13.368)\end{array}$ & $\begin{array}{c}5.649 \\
(14.337)\end{array}$ & $\begin{array}{c}-1.831 \\
(0.624)\end{array}$ & $\begin{array}{c}1.527 \\
(0.640)\end{array}$ \\
\hline ResM2, & $\begin{array}{l}-0.917 \\
(14.814)\end{array}$ & $\begin{array}{c}-0.885 \\
(9.358)\end{array}$ & $\begin{array}{l}-0.867 \\
(10.591)\end{array}$ & $\begin{array}{c}-0.920 \\
(8.243)\end{array}$ & $\begin{array}{c}-1.065 \\
(4.990)\end{array}$ & $\begin{array}{c}-0.928 \\
(9.057)\end{array}$ & $\begin{array}{l}-0.751 \\
(12.521)\end{array}$ \\
\hline $\operatorname{ResM} 2_{t-1}$ & $\begin{array}{l}-1.128 \\
(10.390)\end{array}$ & $\begin{array}{c}-1.023 \\
(6.038)\end{array}$ & $\begin{array}{c}-0.592 \\
(4.027)\end{array}$ & $\begin{array}{c}-0.844 \\
(4.392)\end{array}$ & $\begin{array}{c}-1.411 \\
(4.377)\end{array}$ & $\begin{array}{c}-0.928 \\
(6.725)\end{array}$ & $\begin{array}{c}-0.594 \\
(6.105)\end{array}$ \\
\hline ResM2 $2_{t-2}$ & $\begin{array}{c}-1.058 \\
(7.974)\end{array}$ & $\begin{array}{c}-0.970 \\
(4.779)\end{array}$ & $\begin{array}{c}-0.453 \\
(2.456)\end{array}$ & $\begin{array}{c}-0.919 \\
(3.760)\end{array}$ & $\begin{array}{c}-1.340 \\
(4.057)\end{array}$ & $\begin{array}{c}-1.020 \\
(6.906)\end{array}$ & $\begin{array}{c}-0.562 \\
(4.610)\end{array}$ \\
\hline $\operatorname{ResM} 2_{t-3}$ & $\begin{array}{c}-1.016 \\
(7.669)\end{array}$ & $\begin{array}{c}-0.783 \\
(3.568)\end{array}$ & $\begin{array}{c}-0.555 \\
(2.785)\end{array}$ & $\begin{array}{c}-0.773 \\
(2.969)\end{array}$ & $\begin{array}{c}-1.130 \\
(3.815)\end{array}$ & $\begin{array}{c}-0.757 \\
(5.122)\end{array}$ & $\begin{array}{c}-0.544 \\
(4.308)\end{array}$ \\
\hline ResM2 $2_{t-4}$ & $\begin{array}{c}-0.817 \\
(6.153)\end{array}$ & $\begin{array}{c}-0.601 \\
(2.782)\end{array}$ & $\begin{array}{c}-0.300 \\
(1.582)\end{array}$ & $\begin{array}{c}-0.528 \\
(2.174)\end{array}$ & $\begin{array}{c}-1.316 \\
(4.105)\end{array}$ & $\begin{array}{c}-0.683 \\
(4.261)\end{array}$ & $\begin{array}{c}-0.402 \\
(3.189)\end{array}$ \\
\hline $\operatorname{ResM} 2_{t-5}$ & $\begin{array}{c}-0.481 \\
(4.323)\end{array}$ & $\begin{array}{c}-0.310 \\
(1.651)\end{array}$ & $\begin{array}{c}-0.259 \\
(1.680)\end{array}$ & $\begin{array}{c}-0.299 \\
(1.570)\end{array}$ & $\begin{array}{c}-0.691 \\
(2.324)\end{array}$ & $\begin{array}{c}-0.537 \\
(3.590)\end{array}$ & $\begin{array}{c}-0.261 \\
(2.485)\end{array}$ \\
\hline $\operatorname{ResM} 2_{t-6}$ & $\begin{array}{c}-0.107 \\
(1.688)\end{array}$ & $\begin{array}{c}-0.619 \\
(1.646)\end{array}$ & $\begin{array}{c}-0.187 \\
(2.036)\end{array}$ & $\begin{array}{c}-0.111 \\
(1.022)\end{array}$ & $\begin{array}{c}-0.442 \\
(2.197)\end{array}$ & $\begin{array}{c}-0.371 \\
(3.382)\end{array}$ & $\begin{array}{c}-0.092 \\
(1.392)\end{array}$ \\
\hline
\end{tabular}




\begin{tabular}{|c|c|c|c|c|c|c|c|}
\hline $\log y_{t-1}^{P}$ & $\begin{array}{c}-0.746 \\
(9.522)\end{array}$ & $\begin{array}{c}-0.547 \\
(1.477)\end{array}$ & $\begin{array}{c}-1.166 \\
(6.691)\end{array}$ & $\begin{array}{l}-1.911 \\
(26.612)\end{array}$ & $\begin{array}{l}-1.331 \\
(39.526)\end{array}$ & $\begin{array}{c}-0.649 \\
(1.998)\end{array}$ & $\begin{array}{c}-1.099 \\
(3.056)\end{array}$ \\
\hline $\log R_{L}$ & $\begin{array}{c}-0.008 \\
(0.512)\end{array}$ & $\begin{array}{c}0.046 \\
(1.440)\end{array}$ & $\begin{array}{c}0.001 \\
(0.034)\end{array}$ & $\begin{array}{c}0.064 \\
(2.699)\end{array}$ & $\begin{array}{c}0.355 \\
(3.654)\end{array}$ & $\begin{array}{c}0.045 \\
(1.258)\end{array}$ & $\begin{array}{c}-0.023 \\
(0.717)\end{array}$ \\
\hline $\log y_{t-7}^{t}$ & $\begin{array}{c}-0.075 \\
(1.837)\end{array}$ & $\begin{array}{c}0.021 \\
(0.523)\end{array}$ & $\begin{array}{c}-0.105 \\
(1.455)\end{array}$ & $\begin{array}{c}0.019 \\
(0.240)\end{array}$ & $\begin{array}{c}0.045 \\
(0.618)\end{array}$ & $\begin{array}{c}-0.125 \\
(0.972)\end{array}$ & $\begin{array}{c}-0.084 \\
(1.169)\end{array}$ \\
\hline $\log \mathrm{USPC}_{t}$ & $\begin{array}{c}0.479 \\
(1.991)\end{array}$ & $\begin{array}{c}0.694 \\
(1.955)\end{array}$ & $\begin{array}{c}0.360 \\
(0.984)\end{array}$ & $\begin{array}{c}0.014 \\
(0.040)\end{array}$ & $\begin{array}{c}0.634 \\
(1.318)\end{array}$ & $\begin{array}{c}-0.101 \\
(0.191)\end{array}$ & $\begin{array}{c}-0.606 \\
(1.444)\end{array}$ \\
\hline $\log \mathrm{USPC}_{t-1}$ & $\begin{array}{c}-0.536 \\
(2.809)\end{array}$ & $\begin{array}{c}-0.082 \\
(0.244)\end{array}$ & $\begin{array}{c}-0.550 \\
(1.708)\end{array}$ & $\begin{array}{c}0.506 \\
(1.612)\end{array}$ & $\begin{array}{c}-0.054 \\
(0.106)\end{array}$ & $\begin{array}{c}-0.568 \\
(1.016)\end{array}$ & $\begin{array}{c}0.003 \\
(0.009)\end{array}$ \\
\hline $\log \mathrm{USPC}_{t-2}$ & $\begin{array}{c}-0.503 \\
(2.652)\end{array}$ & $\begin{array}{c}-0.180 \\
(0.543)\end{array}$ & $\begin{array}{c}-0.634 \\
(1.834)\end{array}$ & $\begin{array}{c}-0.448 \\
(1.454)\end{array}$ & $\begin{array}{c}0.269 \\
(0.539)\end{array}$ & $\begin{array}{c}-0.822 \\
(1.459)\end{array}$ & $\begin{array}{c}0.374 \\
(1.105)\end{array}$ \\
\hline $\log \mathrm{USPC}_{t-3}$ & $\begin{array}{c}0.054 \\
(0.221)\end{array}$ & $\begin{array}{c}-0.663 \\
(1.893)\end{array}$ & $\begin{array}{c}0.522 \\
(1.322)\end{array}$ & $\begin{array}{c}-0.043 \\
(0.118)\end{array}$ & $\begin{array}{c}-0.308 \\
(0.691)\end{array}$ & $\begin{array}{c}1.026 \\
(1.995)\end{array}$ & $\begin{array}{c}0.561 \\
(1.286)\end{array}$ \\
\hline $\begin{array}{l}\text { Rho1 } \\
\text { Rho2 }\end{array}$ & $\begin{array}{r}1.7243 \\
-0.8915\end{array}$ & $\begin{array}{r}1.8789 \\
-0.9007\end{array}$ & $\begin{array}{r}1.6919 \\
-0.7642\end{array}$ & $\begin{array}{r}1.5458 \\
-0.6913\end{array}$ & $\begin{array}{r}1.1470 \\
-0.3370\end{array}$ & $\begin{array}{r}1.2111 \\
-0.2419\end{array}$ & $\begin{array}{r}1.7379 \\
-0.7994\end{array}$ \\
\hline $\bar{R}^{2}$ & 0.984 & 0.734 & 0.904 & 0.985 & 0.992 & 0.702 & 0.826 \\
\hline S.E.E. & 0.0057 & 0.0086 & 0.0089 & 0.0086 & 0.0100 & 0.0134 & 0.0098 \\
\hline$D \cdot W$ & 2.02 & 2.04 & 2.48 & 2.09 & 2.09 & 2.01 & 2.11 \\
\hline
\end{tabular}

Note. USPC is the U.S. consumer price index; the other variables are as defined in table 14.1. 
Table 14.7A Price Equation with Dependent Variable $\log \mathrm{PD}-\log (\mathrm{M} 2 / N)$, 1957III to $1976 \mathrm{IV}$ (absolute value of $t$ statistic in parentheses)

\begin{tabular}{|c|c|c|c|c|c|c|c|}
\hline & $\mathrm{CA}$ & FR & GE & IT & JA & $\mathrm{NE}$ & UK \\
\hline \multicolumn{8}{|l|}{ Coefficient } \\
\hline Constant & $\begin{array}{c}0.100 \\
(0.065)\end{array}$ & $\begin{array}{c}3.694 \\
(1.905)\end{array}$ & $\begin{array}{c}3.969 \\
(2.152)\end{array}$ & $\begin{array}{c}9.980 \\
(6.369)\end{array}$ & $\begin{array}{c}5.473 \\
(11.137)\end{array}$ & $\begin{array}{r}-6.822 \\
(2.647)\end{array}$ & $\begin{array}{c}6.855 \\
(2.289)\end{array}$ \\
\hline ResM2, & $\begin{array}{r}-0.442 \\
(2.470)\end{array}$ & $\begin{array}{r}-1.059 \\
(6.001)\end{array}$ & $\begin{array}{r}-0.797 \\
(6.867)\end{array}$ & $\begin{array}{r}-0.736 \\
(4.494)\end{array}$ & $\begin{array}{r}-0.870 \\
(4.715)\end{array}$ & $\begin{array}{r}-0.876 \\
(8.852)\end{array}$ & $\begin{array}{r}-1.029 \\
(9.930)\end{array}$ \\
\hline $\operatorname{ResM} 2_{t-1}$ & $\begin{array}{r}-1.037 \\
(4.720)\end{array}$ & $\begin{array}{r}-1.270 \\
(5.061)\end{array}$ & $\begin{array}{r}-0.495 \\
(3.418)\end{array}$ & $\begin{array}{r}-0.552 \\
(2.675)\end{array}$ & $\begin{array}{r}-1.009 \\
(4.146)\end{array}$ & $\begin{array}{r}-0.872 \\
(7.217)\end{array}$ & $\begin{array}{r}-0.830 \\
(6.482)\end{array}$ \\
\hline $\operatorname{ResM} 2_{t-2}$ & $\begin{array}{r}-0.829 \\
(3.866)\end{array}$ & $\begin{array}{r}-0.992 \\
(3.812)\end{array}$ & $\begin{array}{r}-0.400 \\
(2.629)\end{array}$ & $\begin{array}{r}-0.487 \\
(2.206)\end{array}$ & $\begin{array}{r}-1.085 \\
(4.579)\end{array}$ & $\begin{array}{c}-0.894 \\
(7.128)\end{array}$ & $\begin{array}{c}-0.730 \\
(5.406)\end{array}$ \\
\hline $\operatorname{ResM} 2_{t-3}$ & $\begin{array}{r}-0.845 \\
(4.366)\end{array}$ & $\begin{array}{r}-0.666 \\
(2.538)\end{array}$ & $\begin{array}{r}-0.482 \\
(3.005)\end{array}$ & $\begin{array}{r}-0.432 \\
(1.923)\end{array}$ & $\begin{array}{r}-1.039 \\
(5.270)\end{array}$ & $\begin{array}{r}-0.675 \\
(5.462)\end{array}$ & $\begin{array}{r}-0.932 \\
(7.197)\end{array}$ \\
\hline $\operatorname{ResM} 2_{t-4}$ & $\begin{array}{r}-0.702 \\
(3.098)\end{array}$ & $\begin{array}{r}-0.574 \\
(2.175)\end{array}$ & $\begin{array}{r}-0.316 \\
(2.025)\end{array}$ & $\begin{array}{r}-0.363 \\
(1.625)\end{array}$ & $\begin{array}{c}-0.875 \\
(3.891)\end{array}$ & $\begin{array}{r}-0.580 \\
(4.148)\end{array}$ & $\begin{array}{c}-0.735 \\
(5.442)\end{array}$ \\
\hline $\operatorname{ResM} 2_{t-5}$ & $\begin{array}{r}-0.920 \\
(4.046)\end{array}$ & $\begin{array}{r}-0.430 \\
(1.657)\end{array}$ & $\begin{array}{r}-0.242 \\
(1.518)\end{array}$ & $\begin{array}{r}-0.392 \\
(1.911)\end{array}$ & $\begin{array}{r}-0.364 \\
(1.615)\end{array}$ & $\begin{array}{c}-0.405 \\
(3.047)\end{array}$ & $\begin{array}{c}-0.622 \\
(4.739)\end{array}$ \\
\hline $\operatorname{ResM} 2_{t-6}$ & $\begin{array}{c}-0.303 \\
(1.712)\end{array}$ & $\begin{array}{c}-0.273 \\
(1.458)\end{array}$ & $\begin{array}{c}-0.241 \\
(1.780)\end{array}$ & $\begin{array}{c}-0.081 \\
(0.514)\end{array}$ & $\begin{array}{r}-0.173 \\
(0.983)\end{array}$ & $\begin{array}{c}-0.332 \\
(3.065)\end{array}$ & $\begin{array}{r}-0.314 \\
(2.876)\end{array}$ \\
\hline
\end{tabular}




\begin{tabular}{|c|c|c|c|c|c|c|c|}
\hline $\log \left(y^{P} / N\right)_{t-1}$ & $\begin{array}{c}-0.865 \\
(4.711)\end{array}$ & $\begin{array}{c}-1.253 \\
(6.012)\end{array}$ & $\begin{array}{c}-1.266 \\
(6.381)\end{array}$ & $\begin{array}{l}-1.681 \\
(14.497)\end{array}$ & $\begin{array}{l}-1.316 \\
(33.231)\end{array}$ & $\begin{array}{c}-0.108 \\
(0.381)\end{array}$ & $\begin{array}{c}-1.919 \\
(4.267)\end{array}$ \\
\hline $\log R_{L}$ & $\begin{array}{c}0.072 \\
(1.712)\end{array}$ & $\begin{array}{c}0.106 \\
(1.821)\end{array}$ & $\begin{array}{c}0.007 \\
(0.223)\end{array}$ & $\begin{array}{c}0.125 \\
(3.584)\end{array}$ & $\begin{array}{c}0.367 \\
(4.789)\end{array}$ & $\begin{array}{c}0.004 \\
(0.132)\end{array}$ & $\begin{array}{c}-0.080 \\
(1.451)\end{array}$ \\
\hline $\log y_{t-7}^{t}$ & $\begin{array}{c}0.129 \\
(0.927)\end{array}$ & $\begin{array}{c}-0.074 \\
(0.722)\end{array}$ & $\begin{array}{c}0.269 \\
(1.997)\end{array}$ & $\begin{array}{c}0.476 \\
(3.480)\end{array}$ & $\begin{array}{c}0.130 \\
(1.825)\end{array}$ & $\begin{array}{c}0.091 \\
(0.713)\end{array}$ & $\begin{array}{c}0.272 \\
(1.615)\end{array}$ \\
\hline $\log \mathrm{USPD}_{t}$ & $\begin{array}{c}0.441 \\
(0.828)\end{array}$ & $\begin{array}{c}-0.007 \\
(0.012)\end{array}$ & $\begin{array}{c}-0.741 \\
(1.702)\end{array}$ & $\begin{array}{c}0.473 \\
(1.094)\end{array}$ & $\begin{array}{c}0.636 \\
(2.002)\end{array}$ & $\begin{array}{c}-0.743 \\
(1.715)\end{array}$ & $\begin{array}{c}-0.823 \\
(1.306)\end{array}$ \\
\hline $\log \mathrm{USPD}_{t-1}$ & $\begin{array}{c}-0.859 \\
(1.400)\end{array}$ & $\begin{array}{c}0.679 \\
(1.163)\end{array}$ & $\begin{array}{c}-0.038 \\
(0.075)\end{array}$ & $\begin{array}{c}0.568 \\
(1.152)\end{array}$ & $\begin{array}{c}-0.155 \\
(0.442)\end{array}$ & $\begin{array}{c}-0.666 \\
(1.374)\end{array}$ & $\begin{array}{c}0.458 \\
(0.650)\end{array}$ \\
\hline $\log \mathrm{USPD}_{t-2}$ & $\begin{array}{c}0.710 \\
(1.224)\end{array}$ & $\begin{array}{c}0.111 \\
(0.192)\end{array}$ & $\begin{array}{c}1.024 \\
(2.070)\end{array}$ & $\begin{array}{c}-0.328 \\
(0.664)\end{array}$ & $\begin{array}{c}0.067 \\
(0.198)\end{array}$ & $\begin{array}{c}-0.046 \\
(0.096)\end{array}$ & $\begin{array}{c}0.022 \\
(0.032)\end{array}$ \\
\hline $\log \mathrm{USPD}_{t-3}$ & $\begin{array}{c}-0.616 \\
(1.219)\end{array}$ & $\begin{array}{c}-0.328 \\
(0.664)\end{array}$ & $\begin{array}{c}-0.187 \\
(0.425)\end{array}$ & $\begin{array}{c}-0.977 \\
(2.272)\end{array}$ & $\begin{array}{c}-0.237 \\
(0.708)\end{array}$ & $\begin{array}{c}0.728 \\
(1.813)\end{array}$ & $\begin{array}{c}1.366 \\
(2.158)\end{array}$ \\
\hline Rhol & 0.8455 & 0.9869 & 0.9694 & 0.8934 & 0.8906 & 0.9664 & 0.9604 \\
\hline $\bar{R}^{2}$ & 0.901 & 0.568 & 0.711 & 0.960 & 0.989 & 0.730 & 0.646 \\
\hline S.E.E. & 0.0145 & 0.0153 & 0.0128 & 0.0129 & 0.0089 & 0.0128 & 0.0170 \\
\hline D-W & 1.78 & 0.55 & 0.80 & 1.56 & 1.42 & 1.80 & 1.73 \\
\hline
\end{tabular}

Note. USPD is the U.S. GNP deflator; the other variables are as defined in table 14.1. 
Price Equation with Dependent Variable $\log \mathrm{PD}-\log (\mathrm{M} 2 / N)$, 1957III to 1976IV (absolute value of $t$ statistic in parentheses)

\begin{tabular}{cccccccc}
\hline & CA & FR & GE & IT & JA & NE \\
\hline Coefficient & & & & & & UK \\
Constant & -0.212 & 5.649 & 1.445 & 9.759 & 5.449 & -6.860 \\
& $(0.144)$ & $(2.566)$ & $(0.878)$ & $(6.359)$ & $(11.509)$ & $(2.548)$ & $(1.908)$ \\
ResM2 $t$ & -0.473 & -0.955 & -0.920 & -0.798 & -0.978 & -0.888 & -1.044 \\
& $(2.662)$ & $(9.871)$ & $(12.342)$ & $(4.972)$ & $(4.968)$ & $(9.984)$ & $(10.055)$ \\
ResM2 $t-1$ & -1.052 & -1.075 & -0.704 & -0.549 & -1.038 & -0.879 & -0.850 \\
& $(4.452)$ & $(6.094)$ & $(5.003)$ & $(2.241)$ & $(3.569)$ & $(6.969)$ & $(6.146)$ \\
ResM2 $t-2$ & -0.822 & -0.857 & -0.625 & -0.464 & -1.048 & -0.899 & -0.757 \\
& $(3.488)$ & $(3.994)$ & $(3.436)$ & $(1.613)$ & $(3.616)$ & $(6.779)$ & $(5.016)$ \\
ResM2 $2_{t-3}$ & -0.832 & -0.571 & -0.632 & -0.307 & -1.051 & -0.682 & -0.942 \\
& $(3.817)$ & $(2.464)$ & $(3.249)$ & $(1.032)$ & $(4.186)$ & $(5.182)$ & $(6.382)$ \\
ResM2 $2_{t-4}$ & -0.685 & -0.451 & -0.409 & -0.170 & -1.061 & -0.585 & -0.749 \\
& $(2.745)$ & $(1.996)$ & $(2.215)$ & $(0.595)$ & $(3.817)$ & $(3.984)$ & $(4.915)$ \\
ResM2 $2_{t-5}$ & -0.894 & -0.256 & -0.227 & -0.191 & -0.318 & -0.404 & -0.617 \\
& $(3.616)$ & $(1.294)$ & $(1.532)$ & $(0.800)$ & $(1.165)$ & $(2.927)$ & $(4.291)$ \\
ResM2 $2_{t-6}$ & -0.285 & -0.126 & -0.179 & 0.035 & -0.063 & -0.333
\end{tabular}




\begin{tabular}{|c|c|c|c|c|c|c|c|}
\hline $\log y_{t-1}^{P}$ & $\begin{array}{c}-0.828 \\
(4.742)\end{array}$ & $\begin{array}{c}-1.465 \\
(6.300)\end{array}$ & $\begin{array}{c}-1.000 \\
(5.652)\end{array}$ & $\begin{array}{l}-1.668 \\
(14.723)\end{array}$ & $\begin{array}{l}-1.326 \\
(34.331)\end{array}$ & $\begin{array}{c}-0.105 \\
(0.354)\end{array}$ & $\begin{array}{c}-1.771 \\
(3.807)\end{array}$ \\
\hline $\log R_{L}$ & $\begin{array}{c}0.067 \\
(1.566)\end{array}$ & $\begin{array}{c}-0.077 \\
(2.437)\end{array}$ & $\begin{array}{c}0.004 \\
(0.245)\end{array}$ & $\begin{array}{c}0.105 \\
(2.934)\end{array}$ & $\begin{array}{c}0.307 \\
(3.730)\end{array}$ & $\begin{array}{c}0.002 \\
(0.067)\end{array}$ & $\begin{array}{r}-0.067 \\
(1.162)\end{array}$ \\
\hline $\log y_{t-1}^{t}$ & $\begin{array}{c}0.085 \\
(0.644)\end{array}$ & $\begin{array}{c}0.026 \\
(0.643)\end{array}$ & $\begin{array}{c}0.045 \\
(0.718)\end{array}$ & $\begin{array}{c}0.216 \\
(1.725)\end{array}$ & $\begin{array}{c}0.106 \\
(1.446)\end{array}$ & $\begin{array}{c}0.087 \\
(0.684)\end{array}$ & $\begin{array}{c}0.195 \\
(1.224)\end{array}$ \\
\hline $\log \mathrm{USPD}_{\boldsymbol{t}}$ & $\begin{array}{c}0.225 \\
(0.424)\end{array}$ & $\begin{array}{c}0.062 \\
(0.230)\end{array}$ & $\begin{array}{c}0.062 \\
(0.220)\end{array}$ & $\begin{array}{c}0.385 \\
(0.924)\end{array}$ & $\begin{array}{c}0.317 \\
(0.946)\end{array}$ & $\begin{array}{c}-0.678 \\
(1.572)\end{array}$ & $\begin{array}{c}-0.710 \\
(1.141)\end{array}$ \\
\hline $\log \mathrm{USPD}_{t-1}$ & $\begin{array}{c}-0.793 \\
(1.390)\end{array}$ & $\begin{array}{c}0.500 \\
(2.104)\end{array}$ & $\begin{array}{c}-0.164 \\
(0.710)\end{array}$ & $\begin{array}{c}0.310 \\
(0.792)\end{array}$ & $\begin{array}{c}0.170 \\
(0.513)\end{array}$ & $\begin{array}{c}-0.719 \\
(1.549)\end{array}$ & $\begin{array}{c}0.292 \\
(0.452)\end{array}$ \\
\hline $\log$ USPD $_{t-2}$ & $\begin{array}{c}0.674 \\
(1.257)\end{array}$ & $\begin{array}{c}0.227 \\
(1.001)\end{array}$ & $\begin{array}{c}0.332 \\
(1.416)\end{array}$ & $\begin{array}{c}-0.224 \\
(0.569)\end{array}$ & $\begin{array}{c}0.180 \\
(0.557)\end{array}$ & $\begin{array}{c}-0.090 \\
(0.200)\end{array}$ & $\begin{array}{c}0.008 \\
(0.013)\end{array}$ \\
\hline $\log \mathrm{USPD}_{t-3}$ & $\begin{array}{c}-0.452 \\
(0.888)\end{array}$ & $\begin{array}{c}-0.110 \\
(0.425)\end{array}$ & $\begin{array}{c}-0.533 \\
(1.934)\end{array}$ & $\begin{array}{c}-0.724 \\
(1.756)\end{array}$ & $\begin{array}{c}-0.330 \\
(0.946)\end{array}$ & $\begin{array}{c}0.763 \\
(1.893)\end{array}$ & $\begin{array}{c}1.306 \\
(2.055)\end{array}$ \\
\hline $\begin{array}{l}\text { Rho1 } \\
\text { Rho2 }\end{array}$ & $\begin{array}{r}0.9969 \\
-0.1755\end{array}$ & $\begin{array}{r}1.8884 \\
-0.9312\end{array}$ & $\begin{array}{r}1.7950 \\
-0.8740\end{array}$ & $\begin{array}{r}1.2988 \\
-0.4301\end{array}$ & $\begin{array}{r}1.1178 \\
-0.2634\end{array}$ & $\begin{array}{r}1.0656 \\
-0.1049\end{array}$ & $\begin{array}{r}1.1463 \\
-0.1996\end{array}$ \\
\hline$\vec{R}^{2}$ & 0.916 & 0.831 & 0.915 & 0.966 & 0.991 & 0.731 & 0.656 \\
\hline S.E.E. & 0.0143 & 0.0085 & 0.0082 & 0.0123 & 0.0092 & 0.0127 & 0.0168 \\
\hline D.W & 2.08 & 1.99 & 2.63 & 2.18 & 2.04 & 2.00 & 2.18 \\
\hline
\end{tabular}

Note. USPD is the U.S. GNP deflator; the other variables are as defined in table 14.1. 
Table 14.8A Price Equation with Dependent Variable $\log \mathrm{PC}-\log (\mathrm{M} 2 / N)$, 1957III to 1976IV (absolute value of $t$ statistic in parentheses)

\begin{tabular}{|c|c|c|c|c|c|c|c|c|}
\hline & $\mathrm{CA}$ & FR & GE & IT & JA & NE & UK & US \\
\hline \multicolumn{9}{|l|}{ Coefficient } \\
\hline Constant & $\begin{array}{c}3.595 \\
(2.966)\end{array}$ & $\begin{array}{c}0.758 \\
(0.698)\end{array}$ & $\begin{array}{c}6.039 \\
(6.785)\end{array}$ & $\begin{array}{c}13.764 \\
(10.959)\end{array}$ & $\begin{array}{c}3.230 \\
(5.620)\end{array}$ & $\begin{array}{c}2.494 \\
(2.197)\end{array}$ & $\begin{array}{c}-2.450 \\
(1.220)\end{array}$ & $\begin{array}{c}-0.734 \\
(0.998)\end{array}$ \\
\hline $\operatorname{ResM} 2_{t}$ & $\begin{array}{c}-0.672 \\
(5.416)\end{array}$ & $\begin{array}{c}-1.085 \\
(5.929)\end{array}$ & $\begin{array}{c}-0.829 \\
(8.086)\end{array}$ & $\begin{array}{c}-0.744 \\
(5.778)\end{array}$ & $\begin{array}{c}-0.770 \\
(3.516)\end{array}$ & $\begin{array}{c}-0.852 \\
(8.007)\end{array}$ & $\begin{array}{c}-0.824 \\
(7.982)\end{array}$ & $\begin{array}{c}-1.029 \\
(6.917)\end{array}$ \\
\hline $\operatorname{ResM} 2_{t-1}$ & $\begin{array}{c}-0.880 \\
(5.606)\end{array}$ & $\begin{array}{c}-1.279 \\
(5.244)\end{array}$ & $\begin{array}{c}-0.541 \\
(3.954)\end{array}$ & $\begin{array}{c}-0.650 \\
(3.811)\end{array}$ & $\begin{array}{c}-1.012 \\
(3.542)\end{array}$ & $\begin{array}{c}-0.862 \\
(6.717)\end{array}$ & $\begin{array}{c}-0.733 \\
(5.547)\end{array}$ & $\begin{array}{c}-1.741 \\
(9.589)\end{array}$ \\
\hline $\operatorname{ResM} 2_{t-2}$ & $\begin{array}{c}-0.930 \\
(5.847)\end{array}$ & $\begin{array}{c}-1.137 \\
(4.545)\end{array}$ & $\begin{array}{c}-0.416 \\
(2.768)\end{array}$ & $\begin{array}{c}-0.784 \\
(4.179)\end{array}$ & $\begin{array}{c}-1.065 \\
(3.782)\end{array}$ & $\begin{array}{c}-0.956 \\
(7.308)\end{array}$ & $\begin{array}{c}-0.717 \\
(5.044)\end{array}$ & $\begin{array}{r}-1.762 \\
(8.944)\end{array}$ \\
\hline $\operatorname{ResM} 2_{t-3}$ & $\begin{array}{c}-0.976 \\
(6.924)\end{array}$ & $\begin{array}{c}-0.935 \\
(3.699)\end{array}$ & $\begin{array}{c}-0.538 \\
(3.401)\end{array}$ & $\begin{array}{c}-0.704 \\
(3.652)\end{array}$ & $\begin{array}{c}-0.977 \\
(4.055)\end{array}$ & $\begin{array}{c}-0.690 \\
(5.435)\end{array}$ & $\begin{array}{c}-0.749 \\
(5.514)\end{array}$ & $\begin{array}{c}-1.648 \\
(8.446)\end{array}$ \\
\hline $\operatorname{ResM} 2_{t-4}$ & $\begin{array}{c}-0.806 \\
(5.098)\end{array}$ & $\begin{array}{c}-0.765 \\
(3.001)\end{array}$ & $\begin{array}{c}-0.308 \\
(2.003)\end{array}$ & $\begin{array}{c}-0.544 \\
(2.876)\end{array}$ & $\begin{array}{c}-0.923 \\
(3.362)\end{array}$ & $\begin{array}{c}-0.623 \\
(4.347)\end{array}$ & $\begin{array}{c}-0.663 \\
(4.797)\end{array}$ & $\begin{array}{c}-1.381 \\
(7.082)\end{array}$ \\
\hline $\operatorname{ResM} 2_{t-5}$ & $\begin{array}{r}-0.619 \\
(4.066)\end{array}$ & $\begin{array}{r}-0.545 \\
(2.215)\end{array}$ & $\begin{array}{c}-0.269 \\
(1.790)\end{array}$ & $\begin{array}{r}-0.311 \\
(1.825)\end{array}$ & $\begin{array}{c}-0.497 \\
(1.852)\end{array}$ & $\begin{array}{r}-0.479 \\
(3.439)\end{array}$ & $\begin{array}{r}-0.520 \\
(3.954)\end{array}$ & $\begin{array}{r}-1.056 \\
(5.744)\end{array}$ \\
\hline $\operatorname{ResM} 2_{t-6}$ & $\begin{array}{c}-0.301 \\
(2.540)\end{array}$ & $\begin{array}{c}-0.381 \\
(2.191)\end{array}$ & $\begin{array}{c}-0.201 \\
(1.606)\end{array}$ & $\begin{array}{c}-0.078 \\
(0.604)\end{array}$ & $\begin{array}{c}-0.329 \\
(1.586)\end{array}$ & $\begin{array}{c}-0.332 \\
(2.875)\end{array}$ & $\begin{array}{c}-0.247 \\
(2.262)\end{array}$ & $\begin{array}{c}-0.585 \\
(4.076)\end{array}$ \\
\hline
\end{tabular}




\begin{tabular}{|c|c|c|c|c|c|c|c|c|}
\hline $\log \left(y^{P} / N\right)_{r-1}$ & $\begin{array}{c}-1.320 \\
(9.103)\end{array}$ & $\begin{array}{c}-0.955 \\
(8.311)\end{array}$ & $\begin{array}{l}-1.482 \\
(15.478)\end{array}$ & $\begin{array}{l}-1.957 \\
(21.524)\end{array}$ & $\begin{array}{l}-1.150 \\
(32.398)\end{array}$ & $\begin{array}{c}-1.126 \\
(9.087)\end{array}$ & $\begin{array}{c}-0.506 \\
(1.704)\end{array}$ & $\begin{array}{c}-0.824 \\
(9.756)\end{array}$ \\
\hline $\log R_{L}$ & $\begin{array}{c}0.002 \\
(0.054)\end{array}$ & $\begin{array}{c}0.076 \\
(1.362)\end{array}$ & $\begin{array}{c}0.043 \\
(1.548)\end{array}$ & $\begin{array}{c}0.115 \\
(3.883)\end{array}$ & $\begin{array}{c}0.359 \\
(3.022)\end{array}$ & $\begin{array}{c}0.055 \\
(1.513)\end{array}$ & $\begin{array}{c}-0.054 \\
(1.002)\end{array}$ & $\begin{array}{c}-0.032 \\
(1.463)\end{array}$ \\
\hline $\log y_{t-7}^{t}$ & $\begin{array}{c}0.104 \\
(0.995)\end{array}$ & $\begin{array}{c}-0.081 \\
(0.830)\end{array}$ & $\begin{array}{c}0.043 \\
(0.346)\end{array}$ & $\begin{array}{c}0.180 \\
(1.604)\end{array}$ & $\begin{array}{c}0.108 \\
(1.287)\end{array}$ & $\begin{array}{c}-0.048 \\
(0.350)\end{array}$ & $\begin{array}{c}-0.127 \\
(0.749)\end{array}$ & $\begin{array}{c}0.153 \\
(2.058)\end{array}$ \\
\hline $\log \mathrm{OIL}_{t}$ & $\begin{array}{c}0.004 \\
(0.314)\end{array}$ & $\begin{array}{c}0.017 \\
(1.022)\end{array}$ & $\begin{array}{c}-0.007 \\
(0.547)\end{array}$ & $\begin{array}{c}0.030 \\
(2.437)\end{array}$ & $\begin{array}{c}0.043 \\
(3.041)\end{array}$ & $\begin{array}{c}0.005 \\
(0.338)\end{array}$ & $\begin{array}{c}-0.018 \\
(0.919)\end{array}$ & $\begin{array}{c}0.018 \\
(2.545)\end{array}$ \\
\hline $\log \mathrm{OIL}_{t-1}$ & $\begin{array}{c}0.015 \\
(1.314)\end{array}$ & $\begin{array}{c}0.022 \\
(1.362)\end{array}$ & $\begin{array}{c}-0.002 \\
(0.202)\end{array}$ & $\begin{array}{c}0.011 \\
(0.915)\end{array}$ & $\begin{array}{c}0.018 \\
(1.622)\end{array}$ & $\begin{array}{c}-0.029 \\
(2.062)\end{array}$ & $\begin{array}{c}-0.014 \\
(0.801)\end{array}$ & $\begin{array}{c}0.009 \\
(1.519)\end{array}$ \\
\hline $\log \mathrm{OIL}_{t-2}$ & $\begin{array}{c}0.003 \\
(0.295)\end{array}$ & $\begin{array}{c}0.028 \\
(1.727)\end{array}$ & $\begin{array}{c}0.003 \\
(0.231)\end{array}$ & $\begin{array}{c}0.014 \\
(1.258)\end{array}$ & $\begin{array}{c}0.030 \\
(2.719)\end{array}$ & $\begin{array}{c}-0.020 \\
(1.430)\end{array}$ & $\begin{array}{c}-0.007 \\
(0.396)\end{array}$ & $\begin{array}{c}0.010 \\
(1.575)\end{array}$ \\
\hline $\log \mathrm{OIL}_{t-3}$ & $\begin{array}{c}0.003 \\
(0.229)\end{array}$ & $\begin{array}{c}0.033 \\
(1.905)\end{array}$ & $\begin{array}{c}0.016 \\
(1.172)\end{array}$ & $\begin{array}{c}0.015 \\
(1.305)\end{array}$ & $\begin{array}{c}0.004 \\
(0.324)\end{array}$ & $\begin{array}{c}-0.007 \\
(0.421)\end{array}$ & $\begin{array}{c}0.021 \\
(1.003)\end{array}$ & $\begin{array}{c}0.004 \\
(0.521)\end{array}$ \\
\hline Rho1 & 0.9937 & 0.9876 & 0.9637 & 0.9833 & 0.9561 & 0.9660 & 0.9832 & 0.9685 \\
\hline $\bar{R}^{2}$ & 0.667 & 0.565 & 0.793 & 0.878 & 0.950 & 0.733 & 0.493 & 0.769 \\
\hline S.E.E. & 0.0106 & 0.0146 & 0.0119 & 0.0106 & 0.0108 & 0.0138 & 0.0171 & 0.0614 \\
\hline D.W & 0.79 & 0.55 & 0.99 & 0.92 & 1.37 & 1.64 & 0.54 & 0.65 \\
\hline
\end{tabular}

Note. OIL is the relative price of oil index; the other variables are as defined in table 14.1. PC is the consumer price index. 
Price Equation with Dependent Variable $\log \mathrm{PC}-\log (\mathrm{M} 2 / N)$, 1957III to 1976IV (absolute value of $t$ statistic in parentheses)

\begin{tabular}{ccccccccc}
\hline & CA & FR & GE & IT & JA & NE & UK \\
\hline Coefficient & & & & & & & \\
Constant & 2.796 & 0.173 & 5.863 & 12.929 & 2.774 & 2.505 & -1.155 \\
& $(7.622)$ & $(0.161)$ & $(8.693)$ & $(30.057)$ & $(5.549)$ & $(2.340)$ & $(1.123)$ & -0.095 \\
ResM2 $t$ & -0.927 & -0.934 & -0.871 & -0.875 & -1.006 & -0.919 & -0.727 & -0.962 \\
& $(12.418)$ & $(9.312)$ & $(10.439)$ & $(8.252)$ & $(5.042)$ & $(8.747)$ & $(12.650)$ & $(13.116)$ \\
ResM2 $t-1$ & -1.182 & -1.022 & -0.615 & -0.786 & -1.240 & -0.916 & -0.591 & -1.552 \\
& $(8.959)$ & $(5.960)$ & $(4.187)$ & $(4.261)$ & $(3.869)$ & $(6.507)$ & $(6.113)$ & $(11.532)$ \\
ResM2 $2_{t-2}$ & -1.110 & -0.943 & -0.500 & -0.870 & -1.084 & -1.003 & -0.593 & -1.472 \\
& $(7.029)$ & $(4.642)$ & $(2.679)$ & $(3.677)$ & $(3.159)$ & $(6.716)$ & $(4.811)$ & $(8.392)$ \\
ResM2 $2_{t-3}$ & -1.034 & -0.767 & -0.596 & -0.721 & -0.950 & -0.725 & -0.578 & -1.263 \\
& $(6.650)$ & $(3.525)$ & $(2.926)$ & $(2.840)$ & $(3.022)$ & $(4.891)$ & $(4.566)$ & $(6.907)$ \\
ResM2 $2_{t-4}$ & -0.828 & -0.565 & -0.351 & -0.496 & -0.881 & -0.667 & -0.445 & -0.880 \\
& $(5.302)$ & $(2.638)$ & $(1.829)$ & $(2.082)$ & $(2.609)$ & $(4.107)$ & $(3.596)$ & $(5.068)$ \\
ResM2 $t-5$ & -0.526 & -0.305 & -0.273 & -0.252 & -0.288 & -0.512 & -0.286 & -0.531 \\
& $(3.989)$ & $(1.648)$ & $(1.718)$ & $(1.354)$ & $(0.941)$ & $(3.381)$ & $(2.843)$ & $(3.853)$ \\
ResM2 $2_{t-6}$ & -0.147 & -0.189 & -0.172 & -0.045 & -0.107 & -0.371 & -0.094 & -0.188 \\
& $(1.939)$ & $(1.901)$ & $(1.750)$ & $(0.442)$ & $(0.554)$ & $(3.250)$ & $(1.479)$ & $(2.375)$
\end{tabular}




\begin{tabular}{lcccccccc}
$\log \left(y^{P} / N\right)_{t-1}$ & -1.206 & -0.900 & -1.469 & -1.902 & -1.155 & -1.126 & -0.690 & -0.892 \\
& $(28.786)$ & $(7.871)$ & $(20.079)$ & $(64.910)$ & $(40.114)$ & $(9.658)$ & $(4.565)$ & $(32.717)$ \\
$\log R_{L}$ & 0.013 & 0.051 & 0.023 & 0.069 & 0.168 & 0.061 & -0.005 & -0.014 \\
& $(0.684)$ & $(1.691)$ & $(1.213)$ & $(2.865)$ & $(1.419)$ & $(1.707)$ & $(0.160)$ & $(1.494)$ \\
$\log y_{t-7}^{t}$ & -0.094 & 0.028 & -0.103 & 0.090 & 0.029 & -0.132 & -0.094 & -0.024 \\
& $(1.854)$ & $(0.731)$ & $(1.293)$ & $(1.189)$ & $(0.407)$ & $(0.972)$ & $(1.329)$ & $(0.552)$ \\
$\log$ OIL $_{t}$ & -0.007 & 0.018 & -0.004 & 0.019 & 0.055 & 0.011 & 0.005 & 0.004 \\
& $(1.137)$ & $(2.034)$ & $(0.389)$ & $(2.423)$ & $(4.525)$ & $(0.691)$ & $(0.540)$ & $(1.272)$ \\
$\log$ OIL $_{t-1}$ & -0.020 & 0.019 & -0.009 & -0.001 & 0.023 & -0.030 & -0.015 & 0.002 \\
& $(2.820)$ & $(1.549)$ & $(0.826)$ & $(0.155)$ & $(2.230)$ & $(2.112)$ & $(1.120)$ & $(0.510)$ \\
$\log \mathrm{OIL}_{t-2}$ & -0.023 & 0.026 & -0.003 & 0.002 & 0.032 & -0.019 & -0.016 & 0.005 \\
& $(3.477)$ & $(2.185)$ & $(0.318)$ & $(0.226)$ & $(3.036)$ & $(1.323)$ & $(1.237)$ & $(1.457)$ \\
$\log \mathrm{OIL}_{t-3}$ & -0.006 & 0.028 & 0.007 & 0.006 & 0.010 & -0.008 & -0.018 & 0.008 \\
& $(0.929)$ & $(2.818)$ & $(0.690)$ & $(0.795)$ & $(0.847)$ & $(0.515)$ & $(1.515)$ & $(2.701)$ \\
Rho1 & 1.7477 & 1.8879 & 1.5988 & 1.5661 & 1.4562 & 1.1918 & 1.8294 \\
Rho2 & -0.8802 & -0.9139 & -0.6712 & -0.7201 & -0.5321 & -0.2420 & -0.8946 & -0.7757 \\
$\bar{R}^{2}$ & 0.964 & 0.776 & 0.896 & 0.988 & 0.964 & 0.753 & 0.839 \\
S.E.E. & 0.0069 & 0.0080 & 0.0094 & 0.0082 & 0.0097 & 0.0135 & 0.0097 \\
D-W & 1.95 & 1.98 & 2.45 & 2.00 & 2.16 & 2.07 & 0.965 \\
\hline
\end{tabular}

Note. OIL is the relative price of oil index; the other variables are as defined in table 14.1. PC is the consumer price index. 
Table 14.9A Price Equation with Dependent Variable $\log \mathrm{PD}-\log (\mathrm{M} 2 / N)$, 1957III to 1976IV (absolute value of $t$ statistic in parentheses)

\begin{tabular}{ccccccccc}
\hline & CA & FR & GE & IT & JA & NE & UK \\
\hline Coefficient & & & & & & & \\
Constant & 3.256 & 1.253 & 4.008 & 12.684 & 3.894 & -0.082 & -3.474 \\
& $(2.569)$ & $(1.149)$ & $(4.080)$ & $(8.254)$ & $(9.268)$ & $(0.096)$ & $(1.832)$ & $(1.336)$ \\
ResM2 & -0.557 & -1.804 & -0.846 & -0.732 & -0.830 & -0.857 & -1.001 & -0.928 \\
& $(3.291)$ & $(5.780)$ & $(7.606)$ & $(4.371)$ & $(4.681)$ & $(8.137)$ & $(9.190)$ & $(6.848)$ \\
ResM2 & -1.172 & -1.258 & -0.536 & -0.608 & -0.944 & -0.825 & -0.793 & -1.670 \\
& $(5.477)$ & $(5.033)$ & $(3.612)$ & $(2.734)$ & $(4.085)$ & $(6.500)$ & $(5.690)$ & $(10.090)$ \\
ResM2 $2_{t-2}$ & -0.972 & -1.019 & -0.379 & -0.542 & -0.964 & -0.818 & -0.645 & -1.742 \\
& $(4.479)$ & $(3.977)$ & $(2.323)$ & $(2.214)$ & $(4.235)$ & $(6.341)$ & $(4.302)$ & $(9.702)$ \\
ResM2 $_{t-3}$ & -1.001 & -0.756 & -0.467 & -0.426 & -0.917 & -0.592 & -0.852 & -1.495 \\
& $(5.203)$ & $(2.908)$ & $(2.719)$ & $(1.691)$ & $(4.712)$ & $(4.733)$ & $(5.947)$ & $(8.405)$ \\
ResM2 $_{t-4}$ & -0.773 & -0.602 & -0.255 & -0.313 & -0.722 & -0.522 & -0.707 & -1.129 \\
& $(3.588)$ & $(2.304)$ & $(1.532)$ & $(1.270)$ & $(3.256)$ & $(3.703)$ & $(4.848)$ & $(6.358)$ \\
ResM2 $_{t-5}$ & -1.009 & -0.408 & -0.178 & -0.346 & -0.285 & -0.339 & -0.602 & -0.885 \\
& $(4.869)$ & $(1.616)$ & $(1.090)$ & $(1.555)$ & $(1.313)$ & $(2.474)$ & $(4.340)$ & $(5.279)$ \\
ResM2 $_{t-6}$ & -0.348 & -0.276 & -0.175 & -0.034 & -0.085 & -0.307 & -0.324 & -0.568 \\
& $(2.161)$ & $(1.549)$ & $(1.291)$ & $(0.200)$ & $(0.508)$ & $(2.695)$ & $(2.810)$ & $(4.337)$
\end{tabular}




\begin{tabular}{lcccccccc}
$\log y_{r-1}^{P}$ & -1.261 & -1.003 & -1.272 & -1.886 & -1.203 & -0.853 & -0.369 & -0.793 \\
& $(8.415)$ & $(8.699)$ & $(12.027)$ & $(16.978)$ & $(50.200)$ & $(9.396)$ & $(1.324)$ & $(9.690)$ \\
$\log R_{L}$ & 0.043 & 0.088 & 0.015 & 0.084 & 0.346 & 0.017 & -0.097 & -0.014 \\
& $(1.023)$ & $(1.524)$ & $(0.490)$ & $(2.173)$ & $(3.591)$ & $(0.487)$ & $(1.700)$ & $(0.695)$ \\
$\log y_{t-7}^{t}$ & 0.092 & -0.091 & 0.219 & 0.425 & 0.159 & 0.172 & 0.001 & 0.130 \\
& $(0.646)$ & $(0.911)$ & $(1.621)$ & $(2.910)$ & $(2.380)$ & $(1.271)$ & $(0.005)$ & $(1.900)$ \\
$\log$ OIL $_{t}$ & 0.034 & 0.011 & -0.019 & 0.003 & 0.026 & -0.002 & -0.030 & 0.011 \\
& $(2.084)$ & $(0.608)$ & $(1.299)$ & $(0.211)$ & $(2.261)$ & $(0.160)$ & $(1.485)$ & $(1.715)$ \\
$\log$ OIL $_{t-1}$ & 0.014 & 0.012 & 0.005 & 0.020 & 0.020 & -0.026 & -0.031 & 0.007 \\
& $(0.909)$ & $(0.724)$ & $(0.354)$ & $(1.310)$ & $(2.294)$ & $(1.907)$ & $(1.663)$ & $(1.290)$ \\
$\log$ OIL $_{t-2}$ & 0.031 & 0.030 & 0.003 & 0.010 & 0.021 & -0.016 & 0.051 & 0.009 \\
& $(2.068)$ & $(1.809)$ & $(0.193)$ & $(0.646)$ & $(2.369)$ & $(1.160)$ & $(2.701)$ & $(1.663)$ \\
$\log$ OIL $_{t-3}$ & -0.029 & 0.027 & 0.031 & 0.018 & -0.006 & -0.025 & 0.027 & 0.005 \\
& $(1.818)$ & $(1.502)$ & $(2.129)$ & $(1.184)$ & $(0.559)$ & $(1.611)$ & $(1.194)$ & $(0.853)$ \\
Rhol & 0.9729 & 0.9357 & 0.9656 & 0.9788 & 0.9357 & 0.9326 & 0.9731 & 0.9747 \\
$\bar{R}^{2}$ & 0.627 & 0.980 & 0.718 & 0.819 & 0.980 & 0.778 & 0.601 \\
S.E.E. & 0.0143 & 0.0087 & 0.0130 & 0.0138 & 0.0087 & 0.0135 & 0.0180 \\
D.W & 1.81 & 1.35 & 0.72 & 1.40 & 1.35 & 1.68 & 0.767 \\
\hline
\end{tabular}

Note. OIL is the relative price of oil index; the other variables are as defined in table 14.1. 
Table 14.9B Price Equation with Dependent Variable $\log P D-\log (\mathrm{M} 2 / N)$, 1957III to 1976IV (absolute value of $t$ statistic in parentheses)

\begin{tabular}{ccccccccc}
\hline & CA & FR & GE & IT & JA & NE & UK \\
\hline Coefficient & & & & & & & \\
Constant & 3.287 & 0.987 & 4.309 & 11.624 & 3.840 & -0.197 & -0.089 & -0.588 \\
& $(2.605)$ & $(0.970)$ & $(7.333)$ & $(15.256)$ & $(8.972)$ & $(0.250)$ & $(0.070)$ & $(2.029)$ \\
ResM2 $t$ & -0.583 & -0.883 & -0.967 & -0.844 & -0.931 & -0.901 & -1.026 & -0.915 \\
& $(3.498)$ & $(8.344)$ & $(13.446)$ & $(5.135)$ & $(4.975)$ & $(8.570)$ & $(10.514)$ & $(9.896)$ \\
ResM2 $2_{t-1}$ & -1.195 & -0.953 & -0.726 & -0.628 & -0.925 & -0.859 & -0.820 & -1.582 \\
& $(5.375)$ & $(5.263)$ & $(5.497)$ & $(2.339)$ & $(3.432)$ & $(6.175)$ & $(5.111)$ & $(9.471)$ \\
ResM2 $2_{r-2}$ & -0.976 & -0.767 & -0.598 & -0.505 & -0.899 & -0.844 & -0.777 & -1.603 \\
& $(4.276)$ & $(3.573)$ & $(3.449)$ & $(1.527)$ & $(3.310)$ & $(5.763)$ & $(3.854)$ & $(7.418)$ \\
ResM2 $_{t-3}$ & -1.004 & -0.528 & -0.643 & -0.268 & -0.913 & -0.605 & -0.929 & -1.297 \\
& $(4.884)$ & $(2.298)$ & $(3.360)$ & $(0.766)$ & $(3.820)$ & $(4.179)$ & $(4.502)$ & $(5.768)$ \\
ResM2 $_{t-4}$ & -0.792 & -0.360 & -0.394 & -0.076 & -0.859 & -0.538 & -0.744 & -0.825 \\
& $(3.494)$ & $(1.593)$ & $(2.176)$ & $(0.228)$ & $(3.237)$ & $(3.385)$ & $(3.665)$ & $(3.851)$ \\
ResM2 $_{r-5}$ & -1.022 & -0.138 & -0.233 & -0.113 & -0.157 & -0.350 & -0.530 & -0.555 \\
& $(4.714)$ & $(0.707)$ & $(1.597)$ & $(0.418)$ & $(0.618)$ & $(2.348)$ & $(3.156)$ & $(3.229)$ \\
ResM2 $_{t-6}$ & -0.344 & -0.075 & -0.156 & 0.071 & 0.044 & -0.324 & -0.213 & -0.307 \\
& $(2.144)$ & $(0.712)$ & $(1.835)$ & $(0.444)$ & $(0.247)$ & $(2.847)$ & $(1.973)$ & $(3.079)$
\end{tabular}




\begin{tabular}{lcccccccc}
$\log \left(y^{P} / N\right)_{t-1}$ & -1.265 & -0.978 & -1.309 & -1.807 & -1.205 & -0.839 & -0.836 & -0.829 \\
& $(8.465)$ & $(9.071)$ & $(20.510)$ & $(34.305)$ & $(53.507)$ & $(10.098)$ & $(4.642)$ & $(25.684)$ \\
$\log R_{L}$ & 0.042 & 0.068 & 0.002 & 0.072 & 0.311 & 0.021 & 0.036 & -0.004 \\
& $(0.995)$ & $(2.142)$ & $(0.143)$ & $(1.868)$ & $(2.865)$ & $(0.604)$ & $(0.678)$ & $(0.289)$ \\
$\log y_{t-7}^{t}$ & 0.051 & 0.016 & 0.070 & 0.163 & 0.145 & 0.153 & 0.012 & -0.055 \\
& $(0.373)$ & $(0.400)$ & $(1.085)$ & $(1.301)$ & $(2.086)$ & $(1.143)$ & $(0.095)$ & $(1.020)$ \\
$\log$ OIL & 0.035 & 0.008 & -0.009 & -0.010 & 0.023 & 0.004 & 0.010 & 0.0002 \\
& $(2.154)$ & $(0.864)$ & $(1.027)$ & $(0.776)$ & $(1.945)$ & $(0.264)$ & $(0.674)$ & $(0.071)$ \\
$\log$ OIL $_{t-1}$ & 0.013 & 0.0002 & 0.003 & 0.001 & 0.027 & -0.027 & -0.027 & -0.002 \\
& $(0.815)$ & $(0.002)$ & $(0.307)$ & $(0.100)$ & $(3.060)$ & $(2.064)$ & $(1.560)$ & $(0.461)$ \\
$\log$ OIL $_{t-2}$ & 0.030 & 0.019 & -0.001 & -0.007 & 0.019 & -0.018 & 0.046 & 0.002 \\
& $(2.037)$ & $(1.508)$ & $(0.094)$ & $(0.512)$ & $(2.139)$ & $(1.332)$ & $(2.757)$ & $(0.574)$ \\
$\log$ OIL $_{t-3}$ & -0.028 & 0.009 & 0.023 & 0.005 & -0.003 & -0.030 & -0.021 & 0.005 \\
& $(1.748)$ & $(0.069)$ & $(2.718)$ & $(0.362)$ & $(0.253)$ & $(1.980)$ & $(1.152)$ & $(1.277)$ \\
Rho1 & -1.0846 & 1.8716 & 1.7546 & 1.4179 & 1.1518 & 1.1210 & 1.5894 \\
Rho2 & -0.1170 & -0.9007 & -0.8320 & -0.5375 & -0.2386 & -0.2124 & -0.6864 & -0.7950 \\
$\bar{R}^{2}$ & 0.628 & 0.800 & 0.914 & 0.956 & 0.982 & 0.806 & 0.789 \\
S.E.E. & 0.0143 & 0.0084 & 0.0082 & 0.0120 & 0.0090 & 0.0133 & 0.0153 \\
D-W & 2.03 & 1.86 & 2.60 & 2.29 & 2.11 & 2.20 & 0.948 \\
\hline
\end{tabular}

Note. OIL is the relative price of oil index; the other variables are as defined in table 14.1. 


\section{References}

Al-Khuri, S., and S. M. Nsouli. 1978. The Speed of Adjustment of the actual to the desired money stock: A comparative study. European Economic Review 11: 181-206.

Barro, H. J. 1978. Unanticipated money, output, and the price level in the United States. Journal of Political Economy 86: 549-80.

Blinder, A. S., and S. Fischer. 1978. Inventories, rational expectations, and the business cycle. MIT working paper, June.

Bordo, M. D., and L. Jonung. 1981. The long run behavior of the income velocity of money in five advanced countries, 1870-1975: An institutional approach. Economic Inquiry 19 (January): 96-116.

Boughton, J. M. 1979. Demand for money in major OECD countries. OECD Economic Outlook Occasional Studies, January, pp. 35-57.

Brunner, K., and A. H. Meltzer, eds. 1978. Carnegie-Rochester conference Series on public policy: A supplement to the Journal of Monetary Economics, vol. 8. Amsterdam: North-Holland.

Cagan, P. 1980. Imported inflation, 1973-74, and the accommodation issue. Journal of Money, Credit and Banking 12, no. 1 (February): $1-16$.

Carr, J., and M. Darby. 1981. The role of money supply shocks in the short-run demand for money. Journal of Monetary Economics 8 (September): 183-99.

Coats, W. L., Jr. 1979. Modeling the short-run demand for money with exogenous supply. Board of Governors of the Federal Reserve System, unpublished, June.

Darby, M. R. 1972. The allocation of transitory income among consumers' assets. American Economic Review 62 (December): 928-41.

Dewald, W., and M. Marchon. 1978. A modified Federal Reserve of St. Louis spending equation for Canada, France, Germany, Italy, the United Kingdom, and the United States. Kredit und Kapital, vol. 11, no. 2.

Frenkel, J. A., and C. A. Rodriguez. 1975. Portfolio equilibrium and the balance of payments: A monetary approach. American Economic Review 64, no. 4: 674-88.

Friedman, M., and A. J. Schwartz. 1963. A monetary history of the United States, 1867-1960. Princeton: Princeton University Press.

- 1982. Monetary trends in the United States and the United Kingdom: Their relation to income, prices, and interest rates, 1867-1975. Chicago: University of Chicago Press.

Gandolfi, A. E., and J. R. Lothian. 1976. The demand for money from the great depression to the present. American Economic Review 66: $46-51$. 
Gordon, R. J. 1980. A consistent characterization of a near-century of price behavior. American Economic Review 70, no. 2: 243-49.

Griliches, Z. 1961. A note on serial correlation bias in estimates of distributed lags. Econometrica 29 (January): 65-73.

Hafer, R. W., and S. E. Hein. 1980. The dynamics and estimation of short-run money. Federal Reserve Bank of St. Louis Review, March, pp. 26-35.

Huffman, W. E., and J. R. Lothian. 1980. Money in the U.K., 18331880. Journal of Money, Credit and Banking 12, no. 2: 155-74.

Laidler, D. 1977. The demand for money: Theories and evidence. $2 \mathrm{~d}$ ed. New York: Dun-Donnelly. 1980. The demand for money in the United States-yet again. In K. Brunner and A. H. Meltzer, eds., Carnegie-Rochester conference series on public policy on the state of macro-economics, vol. 12. Amsterdam: North-Holland, pp. 219-72.

Lothian, J. R. 1976. The demand for high-powered money. American Economic Review, 66 (March): 56-68.

Lucas, R. E., Jr. 1973. Some international evidence on output-inflation tradeoffs. American Economic Review 63 (June): 326-34.

Martino, A. 1980. Another Italian economic miracle? Unpublished, Mont Pelerin Society meeting, Stanford. 